Article

\title{
Copper(II) Thiosemicarbazone Complexes and Their Proligands upon UVA Irradiation: An EPR and Spectrophotometric Steady-State Study
}

\author{
Michal Hricovíni ${ }^{1}$, Milan Mazúr ${ }^{1}$, Angela Sîrbu ${ }^{2}$, Oleg Palamarciuc ${ }^{2}$, Vladimir B. Arion ${ }^{3}$ \\ and Vlasta Brezová ${ }^{1, *}$ \\ 1 Institute of Physical Chemistry and Chemical Physics, Faculty of Chemical and Food Technology, Slovak \\ University of Technology in Bratislava, Radlinského 9, SK-812 37 Bratislava, Slovak Republic; \\ michal.hricovini@stuba.sk (M.H.); milan.mazur@stuba.sk (M.M.) \\ 2 Department of Chemistry, Moldova State University, A. Mateevici Street 60, MD-2009 Chisinau, Moldova; \\ sirbuangela@yandex.ru (A.S.); palamarciuco@gmail.com (O.P.) \\ 3 Institute of Inorganic Chemistry, University of Vienna, Währinger Strasse 42, A-1090 Vienna, Austria; \\ vladimir.arion@univie.ac.at \\ * Correspondence: vlasta.brezova@stuba.sk; Tel.: +421-259-325-666
}

Academic Editor: Derek J. McPhee

Received: 27 February 2018; Accepted: 19 March 2018; Published: 21 March 2018

\begin{abstract}
X- and Q-band electron paramagnetic resonance (EPR) spectroscopy was used to characterize polycrystalline $\mathrm{Cu}$ (II) complexes that contained sodium 5-sulfonate salicylaldehyde thiosemicarbazones possessing a hydrogen, methyl, ethyl, or phenyl substituent at the terminal nitrogen. The ability of thiosemicarbazone proligands to generate superoxide radical anions and hydroxyl radicals upon their exposure to UVA irradiation in aerated aqueous solutions was evidenced by the EPR spin trapping technique. The UVA irradiation of proligands in neutral or alkaline solutions and dimethylsulfoxide (DMSO) caused a significant decrease in the absorption bands of aldimine and phenolic chromophores. Mixing of proligand solutions with the equimolar amount of copper(II) ions resulted in the formation of 1:1 Cu(II)-to-ligand complex, with the EPR and UV-Vis spectra fully compatible with those obtained for the dissolved $\mathrm{Cu}$ (II) thiosemicarbazone complexes. The formation of the complexes fully inhibited the photoinduced generation of reactive oxygen species, and only subtle changes were found in the electronic absorption spectra of the complexes in aqueous and DMSO solutions upon UVA steady-state irradiation. The dark redox activity of copper(II) complexes and proligand $/ \mathrm{Cu}(\mathrm{II})$ aqueous solutions towards hydrogen peroxide which resulted in the generation of hydroxyl radicals, was confirmed by spin trapping experiments.
\end{abstract}

Keywords: sodium 5-sulfonate-salicylaldehyde thiosemicarbazones; copper(II) complexes; Q- and $\mathrm{X}$-band EPR spectroscopy; spin trapping; UVA exposure; reactive oxygen species

\section{Introduction}

Aromatic and heteroaromatic thiosemicarbazones (TSCs) and their transition metal complexes have gained considerable attention due to their coordination chemistry and broad range of biological activities [1-9]. The biological actions of thiosemicarbazones are often related to the chelation of metal ions, especially regarding coordination with biologically relevant transition metal ions [10-15]. For example, $\mathrm{Cu}$ (II)-TSC complexes are effective anticancer agents, and act as strong inhibitors of DNA synthesis via the inhibition of ribonucleotide reductase [16-18]. The position and type of substituent on the TSC backbone, along with the character of the metal ion, have a strong impact on the overall properties and stability of the coordination compound, as well as its biological activity. The presence 
of amide, imine, and thione groups in the thiosemicarbazone molecule are responsible for its excellent metal ion chelating capacity [19-21].

Despite the low water-solubility of (hetero)/aromatic TSCs, suitable modification of their structure may result in enhanced solubility in aqueous media, which is highly desirable for applications in vivo. For example, when salicylaldehyde thiosemicarbazone is coupled with prolines a significant increase in water solubility is observed [22-24]. In particular, when coordinated to $\mathrm{Cu}$ (II) ions, these TSC-derivatives exhibit cytotoxic activity against ovarian carcinoma $\mathrm{CH} 1$ cells [25-27]. A new series of sodium 5-sulfonate-salicylaldehyde thiosemicarbazones containing different substituents at the terminal nitrogen atom (L1-L4 in Scheme 1) was synthesized recently, with the aim to obtain water-soluble TSC derivatives with potential biological activity. Proligands L1-L4 and their $\mathrm{Cu}(\mathrm{II})$ complexes (1-4 in Scheme 1) were characterized by different spectroscopic techniques, electrospray ionization (ESI) mass spectrometry, X-ray crystallography and cyclic voltammetry [28]. The behavior of proligands L1-L4 in aqueous media is determined by the presence of two dissociable hydrogens; the first dissociation step was assigned to the deprotonation of the phenolic group with $\mathrm{p} K_{1}$ values in the range of 7.73-7.82, without any noticeable effect of substituents at the terminal nitrogen [28]. The second deprotonation step, attributed to the loss of a proton from the hydrazinic NH-group of thiosemicarbazide moiety, is observable in a strongly basic medium [28]. While TSC-derivatives L1-L4 demonstrated only limited cytotoxicity against the human cancer cell lines, the corresponding $\mathrm{Cu}$ (II) complexes showed moderate anticancer activity, coupled with the ability to induce the accumulation of reaction oxygen species (ROS) in target cells, which was confirmed by using $2^{\prime}, 7^{\prime}$-dichlorodihydrofluorescein diacetate, which, in the presence of ROS, was subsequently converted into the highly fluorescent $2^{\prime}, 7^{\prime}$-dichlorofluorescein [28].

1

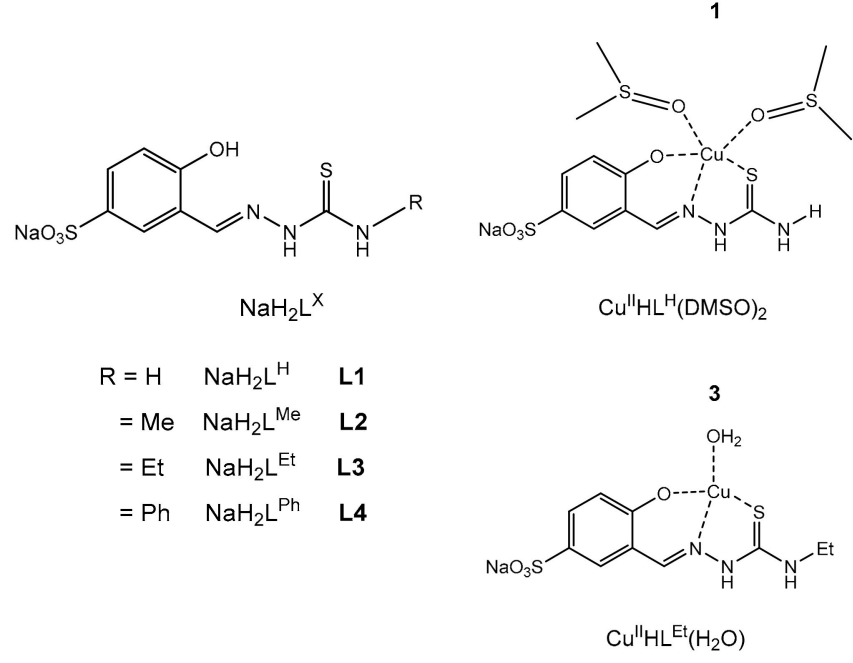

2
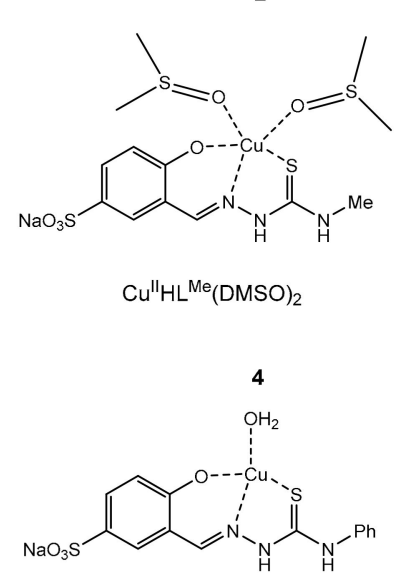

$\mathrm{Cu}^{\mathrm{II}} \mathrm{HL}^{\mathrm{Ph}}\left(\mathrm{H}_{2} \mathrm{O}\right)$

Scheme 1. Line drawings of the investigated thiosemicarbazone proligands L1-L4 and their $\mathrm{Cu}(\mathrm{II})$ complexes (1-4).

Development of anticancer drugs is a multiparameter task, which requires, among other things, elucidation of the photostability of the potential drugs in a biocompatible media, in order to avoid the undesired rapid decomposition of the active species. The photochemical instability of some pharmaceutical products may lead to undesired side effects during their applications, as well as problems in handling and administration [29-33]. Herein, we studied the effect of UVA exposure on both metal-free proligands, and their copper(II) complexes, and, in particular, the ability of compounds to generate ROS upon irradiation. The electron paramagnetic resonance (EPR) spin trapping technique with 5,5-dimethyl-1-pyrroline $\mathrm{N}$-oxide (DMPO) as the spin trap was applied to follow the generation of ROS upon UVA irradiation of complexes 1-4, and proligands L1-L4 in water or DMSO. Cu(II) complexes revealed high photostability and limited capacity to produce ROS; however, upon UVA exposure, 
photoexcitation of proligands L1-L4 caused significant changes in their electronic spectra; these changes were attributable to interactions with generated ROS (hydroxyl radicals, superoxide radical anions) found using spin trapping. In addition, hydroxyl radical formation was confirmed in cell-free experiments investigating the dark redox activity of $\mathrm{Cu}$ (II) complexes with hydrogen peroxide by undertaking EPR spin trapping experiments. This agrees well with the previously reported data on cancer cells [28].

\section{Results and Discussion}

\subsection{EPR Spectra of Polycrystalline Cu(II) Complexes}

Figure 1 summarizes the $\mathrm{X}$ - and Q-band electron paramagnetic resonance (EPR) spectra of polycrystalline $\mathrm{Cu}(\mathrm{II})$ complexes $\mathbf{1 - 4}$ measured at $100 \mathrm{~K}$, although fully compatible EPR spectra were obtained already at room temperature. For complexes 1-3, axially symmetric EPR spectra with unresolved hyperfine couplings were measured in both frequency domains, while better $g$-tensor components resolution was provided by the Q-band (Figure 1b). The values of $g_{\|}$and $g_{\perp}$, refined by computer simulations, of the experimental EPR spectra of complexes 1-3 (Table 1) matched well with the relation $g_{\|}>g_{\perp}>2.0023$, which is consistent with the $\mathrm{d}_{\mathrm{x} 2-\mathrm{y} 2}$ ground electronic state of the $\mathrm{Cu}(\mathrm{II})$ ion. To obtain more detailed information, we evaluated the parameter $\mathrm{G}=\left(g_{\|}-2\right) /\left(g_{\perp}-2\right)$ as a measure of the exchange interaction between copper centers in the polycrystalline solid [34,35]. The G-values of 2.91 or 3.31, both below 4, were calculated from X-and Q-band spectra of complex 3, respectively, indicating an exchange interaction in this complex in the solid state. In contrast, G-values higher than 4 were obtained from the spectra of complexes $\mathbf{1}$ and 2; this indicated only a negligible exchange interaction, which correlated well with the differences in structure found previously by the single crystal X-ray diffraction of complexes 1-3 [28].

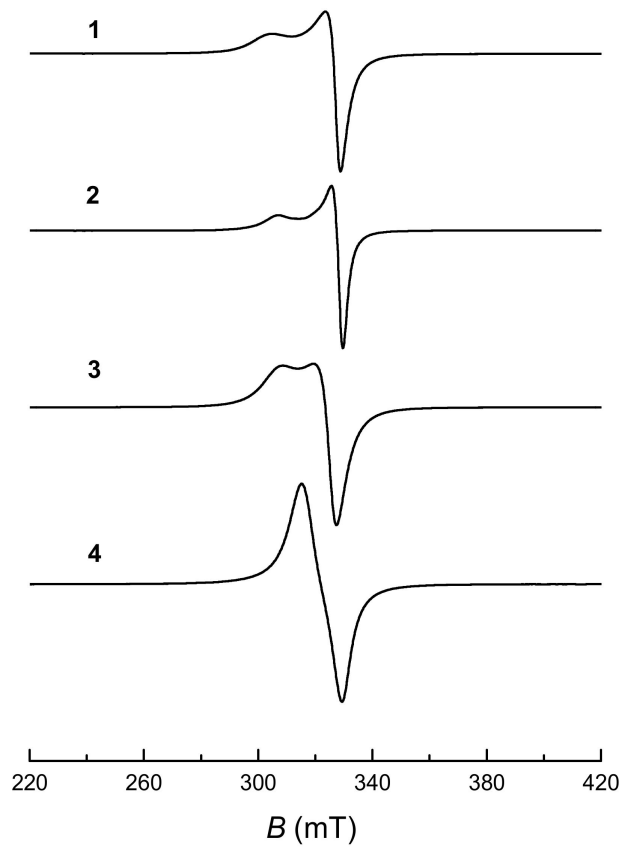

(a)

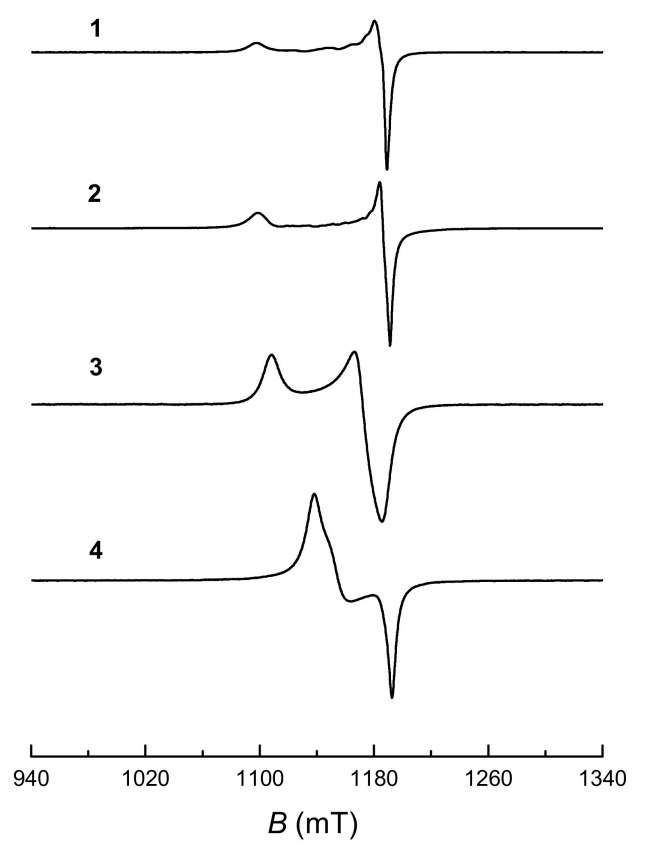

(b)

Figure 1. X-band (a) and Q-band (b) electron paramagnetic resonance (EPR) spectra of polycrystalline $\mathrm{Cu}$ (II) complexes 1-4 measured at $100 \mathrm{~K}$. EPR spectrometer settings: (a) microwave frequency, $9.458 \mathrm{GHz}$; microwave power, $10.03 \mathrm{~mW}$; center field, $320 \mathrm{mT}$; gain, $7.1 \times 10^{2}$; modulation amplitude, $0.5 \mathrm{mT}$; scan, $84 \mathrm{~s}$; time constant, $40.96 \mathrm{~ms}$; (b) microwave frequency, $33.999 \mathrm{GHz}$; microwave power, $2.28 \mathrm{~mW}$; center field, $1140 \mathrm{mT}$; gain, $2.0 \times 10^{1}$; modulation amplitude, $0.05 \mathrm{mT}$; scan, $121 \mathrm{~s}$; time constant, $163.84 \mathrm{~ms}$. The spin-Hamiltonian parameters evaluated from the simulations are summarized in Table 1. 
Solid-state structural analysis of $\mathbf{1}$ and $\mathbf{2}$ confirmed the coordination of copper(II), provided by the ONS-donor set of the Schiff base ligand and two molecules of DMSO bound in equatorial and apical positions, with the geometry of the central atom corresponding to a slightly-distorted square-pyramidal coordination [28]. The crystal structures of $\mathbf{1}$ and $\mathbf{2}$ are stabilized by a system of $\mathrm{N}-\mathrm{H}$... O hydrogen bonds forming a 3D supramolecular network. On the other hand, the structure of 3 consists of two asymmetric $\mathrm{Cu}(\mathrm{II})$ entities, with the square-pyramidal coordination geometry of the central atom linked through the centre of symmetry, forming a tetranuclear complex. The main crystal structural motif for 3 can be described as a 3D supramolecular network based on the $\mathrm{O}-\mathrm{H} \cdots \mathrm{O}$ and $\mathrm{O}-\mathrm{H} \cdots \mathrm{N}$ hydrogen bonding [28]. The Xand Q-band EPR spectra of polycrystalline complex 4 revealed rhombic features that were well resolved, especially at higher frequency; no hyperfine coupling was found (Figure 1b). The orthorhombic $g$-tensor components that were evaluated from the simulation of the experimental spectra are gathered in Table 1.

The simulation analysis of EPR spectra at both frequencies revealed the following order $g_{\|}(\mathbf{1})>g_{\|}(\mathbf{2})>g_{\|}(\mathbf{3})>g_{z}(\mathbf{4})$ (Table 1$)$, which may reflect the changes in the interaction along the $z$-axis due to the steric effect of the substituent directly bound to the terminal amine nitrogen (Scheme 1). Consequently, the relationship of $g_{\|}$or $g_{z}$ vs. Taft-Dubois steric parameter $\mathrm{E}_{\mathrm{S}}{ }^{\prime}$ was analyzed [36,37]. The linear dependence obtained for complexes 1-4 in both frequency domains evidenced the impact of the increased steric hindrance caused by the presence of hydrogen (1), methyl (2), ethyl (3), or phenyl (4) groups, on the coordination geometry of the central atom (Figure 2). The EPR spectra of polycrystalline compounds 1-3 showed an axial symmetry, while the rhombic spectra were observed for complex 4 which possessed the phenyl substitution with the highest steric demand on the terminal nitrogen (Figure 1, Table 1).

Table 1. Spin-Hamiltonian parameters elucidated from the simulations of the experimental EPR spectra of polycrystalline copper(II) complexes 1-4 measured at $100 \mathrm{~K}$.

\begin{tabular}{|c|c|c|c|c|c|c|c|c|}
\hline \multirow{3}{*}{$\begin{array}{c}\mathrm{Cu}(\mathrm{II}) \\
\text { Complex }\end{array}$} & \multicolumn{8}{|c|}{ Spin-Hamiltonian Parameters } \\
\hline & \multicolumn{4}{|c|}{ X-Band } & \multicolumn{4}{|c|}{ Q-Band } \\
\hline & \multicolumn{2}{|c|}{$g_{\perp}{ }^{1}$} & $g_{\|}^{1}$ & $g_{\mathrm{av}}{ }^{2}$ & \multicolumn{2}{|c|}{$g_{\perp}{ }^{3}$} & $g_{\|}^{3}$ & $g_{\mathrm{av}}{ }^{2}$ \\
\hline 1 & \multicolumn{2}{|c|}{2.055} & 2.222 & 2.111 & \multicolumn{2}{|c|}{2.046} & 2.215 & 2.102 \\
\hline 2 & \multicolumn{2}{|c|}{2.048} & 2.199 & 2.098 & \multicolumn{2}{|c|}{2.043} & 2.212 & 2.099 \\
\hline \multirow[t]{2}{*}{3} & \multicolumn{2}{|c|}{2.067} & 2.195 & 2.109 & \multicolumn{2}{|c|}{2.058} & 2.192 & 2.103 \\
\hline & $g_{x}{ }^{1}$ & $g_{y}{ }^{1}$ & $g_{z}{ }^{1}$ & $g_{\mathrm{av}}{ }^{2}$ & $g x^{3}$ & $g_{y}^{3}$ & $g z^{3}$ & $g_{\mathrm{av}}{ }^{2}$ \\
\hline 4 & 2.045 & 2.104 & 2.132 & 2.093 & 2.038 & 2.099 & 2.135 & 2.090 \\
\hline
\end{tabular}

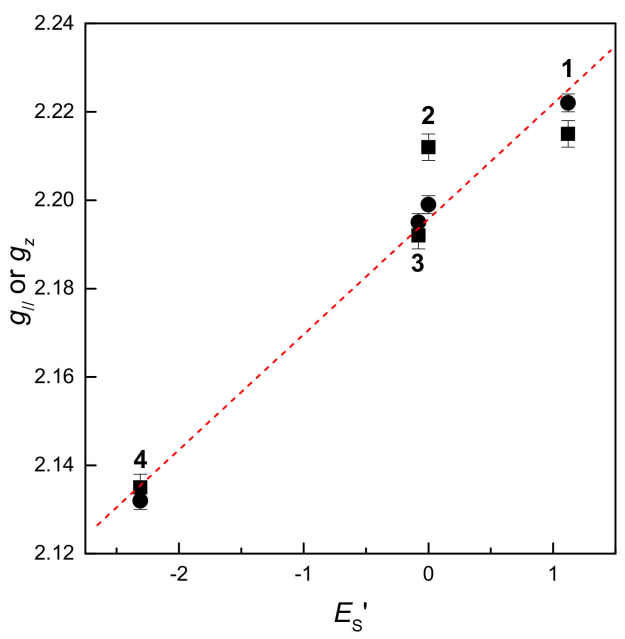

Figure 2. Relationship of $g_{\|}$or $g_{z}$ values evaluated from simulation of X-band $(\bullet)$ and Q-band spectra of polycrystalline $\mathrm{Cu}(\mathrm{II})$ complexes $\mathbf{1}-\mathbf{4}$ vs. the Taft-Dubois steric parameter $E_{\mathrm{s}}{ }^{\prime}$ [36]. 


\section{2. $\mathrm{Cu}(\mathrm{II})$ Complexes in Solution}

The $\mathrm{Cu}$ (II) complexes 1-4, as well as the corresponding proligands, reveal a moderate solubility in water and DMSO, and consequently further EPR and UV-Vis experiments were performed using these solvents. The EPR spectra of $\mathrm{Cu}(\mathrm{II})$ complexes $\mathbf{1 - 4}$, measured at $298 \mathrm{~K}$ in DMSO or water, showed hyperfine coupling of $\mathrm{Cu}$ (II) $(I=3 / 2)$ and one nitrogen nucleus $(I=1)$, due to the equatorial coordination of one nitrogen atom in the 1:1 copper(II)-to-ligand complexes, as illustrated in Figure 3 for complex 4. The nitrogen hyperfine coupling was only partially resolved, especially in the more viscous DMSO [37], due to restricted molecular tumbling, leading to line-broadening [38-40]. Consequently, in order to improve the resolution, the EPR spectra were measured in the temperature range of 298-348 K. The temperature increase led to a better resolved nitrogen hyperfine splitting without any significant changes of the $\mathrm{Cu}(\mathrm{II})$ pattern (Figure $3 \mathrm{~b}$ ). The analogous effect of temperature increase was found in both solvents. The spin-Hamiltonian parameters for 1-4 $\left(g, A_{\mathrm{Cu}}\right.$ and $A_{\mathrm{N}}$; summarized in Table 2 for $298 \mathrm{~K}$ ) were elucidated from the detailed simulations of the X-band EPR spectra. The EPR spectrum of 4 was also measured in a frozen DMSO solution at $100 \mathrm{~K}$, and the averaging of the anisotropic spin-Hamiltonian parameters elucidated from its simulation $\left(g_{x}=2.057, g_{y}=2.040\right.$, $g_{z}=2.227 ; A_{\mathrm{Cu}, x}=2.30 \mathrm{mT}, A_{\mathrm{Cu}, y}=1.78 \mathrm{mT}, A_{\mathrm{Cu}, z}=18.07 \mathrm{mT} ; A_{\mathrm{N}, x}=1.46 \mathrm{mT}, A_{\mathrm{N}, y}=1.82 \mathrm{mT}$, $A_{\mathrm{N}, z}=2.23 \mathrm{mT}$ ), gave the values of $g_{\mathrm{av}}=2.108, A_{\mathrm{Cu}, \mathrm{av}}=7.38 \mathrm{mT}$ and $A_{\mathrm{N}, \mathrm{av}}=1.84 \mathrm{mT}$, which matched well with the corresponding parameters obtained from the spectra measured in DMSO solutions at $298 \mathrm{~K}$ (Table 2). This confirms that the coordination mode is preserved after freezing, analogously to the previously described $\mathrm{Cu}$ (II) complex of salicylaldehyde thiosemicarbazone (STSC) in water [38].

Figure 3 shows the EPR spectra of 4 in DMSO at varying temperatures ( $298 \mathrm{~K}$ and $348 \mathrm{~K}$ ), in water at $298 \mathrm{~K}$, along with the spectra acquired at $298 \mathrm{~K}$ by mixing the equimolar $(1 \mathrm{mM})$ aqueous solutions of the proligand $\mathrm{L} 4(\mathrm{pH}=7)$ and $\mathrm{CuSO}_{4}$ (Figure 3d). Identical EPR spectra were found for 4 in water and in equimolar mixture $\mathrm{L4} / \mathrm{CuSO}_{4}$ (Figure 3c,d), evidencing the formation of the 1:1 Cu(II)-to-ligand complex via the ONS-donor set in the mixture under given experimental conditions. Analogously, the addition of an equimolar buffered solution $(\mathrm{pH}=7)$ of proligands $\mathbf{L 1}-\mathbf{L} 3$ to $\mathrm{CuSO}_{4}$ in water led to the immediate formation of $\mathrm{Cu}$ (II) complexes, with the EPR spectra fully compatible with those measured in the aqueous solutions of 1-3. Such behavior of proligands matches well with the results of our previous spectrophotometric investigations of complex formation in the aqueous solutions containing L1-L4 and copper(II) ions [28].

Table 2. Spin-Hamiltonian parameters elucidated from the simulations of the experimental X-band EPR spectra of copper(II) complexes 1-4 measured at $298 \mathrm{~K}$ in DMSO and water.

\begin{tabular}{|c|c|c|c|c|c|c|c|c|c|c|c|c|}
\hline \multirow{2}{*}{$\begin{array}{c}\text { Cu(II) } \\
\text { Complex }\end{array}$} & \multicolumn{4}{|c|}{$g$-Value ${ }^{1}$} & \multicolumn{8}{|c|}{ Hyperfine Coupling (mT) } \\
\hline & $g_{x}$ & $g_{y}$ & $g_{z}$ & $g_{\text {av }}$ & $A_{\mathrm{Cu}, x}$ & $A_{\mathrm{Cu}, y}$ & $A_{\mathrm{Cu}, z}$ & $A_{\mathrm{Cu}, \mathrm{av}}$ & $A_{\mathrm{N}, x}$ & $A_{\mathrm{N}, y}$ & $A_{\mathrm{N}, z}$ & $A_{\mathrm{N}, \mathrm{av}}$ \\
\hline & \multicolumn{12}{|c|}{ Dimethylsulfoxide } \\
\hline 1 & 2.0994 & 2.0935 & 2.0944 & 2.0958 & 7.02 & $7.44^{\circ}$ & 6.92 & 7.13 & 2.16 & 1.46 & 1.73 & 1.78 \\
\hline 2 & 2.0923 & 2.0850 & 2.0934 & 2.0902 & 6.99 & 7.43 & 7.21 & 7.21 & 2.05 & 1.61 & 1.81 & 1.82 \\
\hline 3 & 2.0909 & 2.0938 & 2.0945 & 2.0931 & 7.02 & 7.39 & 7.38 & 7.26 & 1.87 & 1.71 & 1.67 & 1.75 \\
\hline \multirow[t]{2}{*}{4} & 2.0966 & 2.0931 & 2.1073 & 2.0990 & 7.13 & 7.46 & 7.59 & 7.39 & 1.75 & 1.81 & 1.88 & 1.81 \\
\hline & \multicolumn{12}{|c|}{ Water } \\
\hline 1 & 2.0955 & 2.1049 & 2.0997 & 2.1000 & 6.89 & 7.30 & 7.38 & 7.19 & 1.97 & 1.76 & 1.69 & 1.81 \\
\hline 2 & 2.0931 & 2.1007 & 2.0965 & 2.0968 & 7.37 & 7.28 & 7.53 & 7.39 & 1.93 & 1.66 & 1.56 & 1.72 \\
\hline 3 & 2.0967 & 2.0989 & 2.0968 & 2.0975 & 7.28 & 7.38 & 7.23 & 7.30 & 1.70 & 1.73 & 1.81 & 1.75 \\
\hline 4 & 2.0971 & 2.0948 & 2.1065 & 2.0995 & 7.20 & 7.15 & 7.93 & 7.43 & 1.93 & 1.59 & 1.63 & 1.72 \\
\hline
\end{tabular}




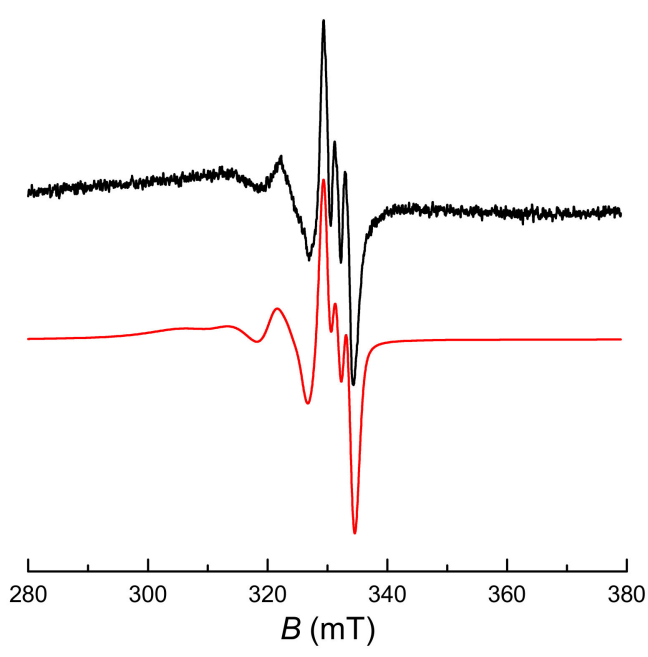

(a)

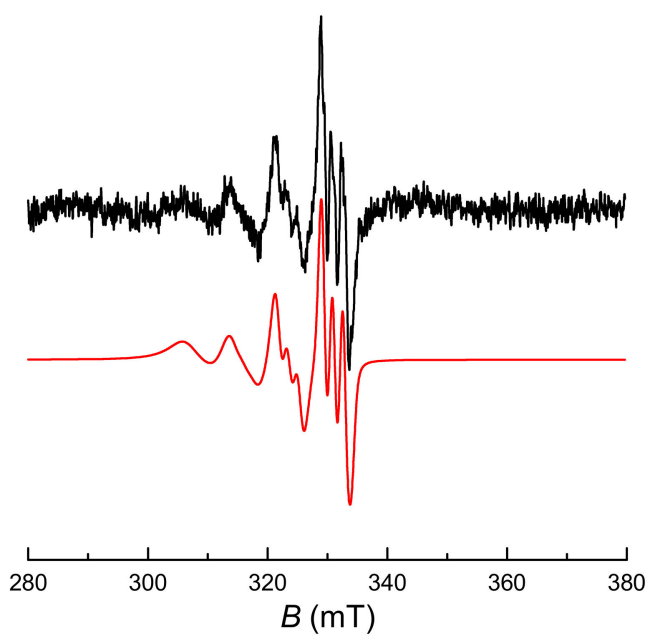

(c)

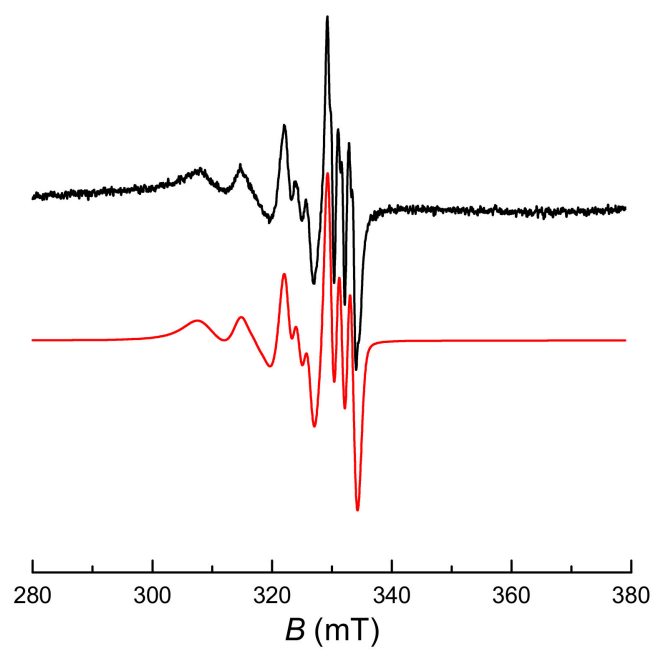

(b)

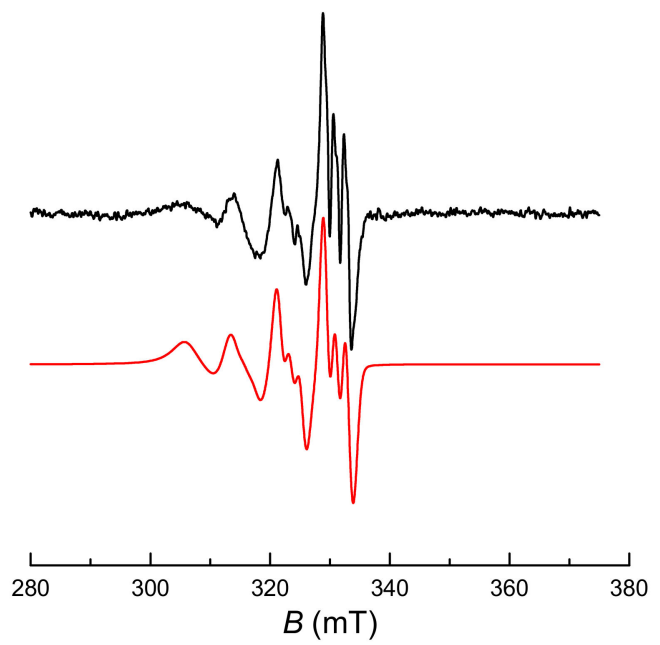

(d)

Figure 3. The experimental (-) and simulated (-) EPR spectra of 4 in DMSO (0.8 mM) at $298 \mathrm{~K}(\mathbf{a})$ or $348 \mathrm{~K}(\mathbf{b})$ and in $\mathrm{H}_{2} \mathrm{O}(0.4 \mathrm{mM})$ at $298 \mathrm{~K}(\mathbf{c})$; EPR spectrum obtained by mixing the equimolar $(1 \mathrm{mM})$ aqueous solutions of proligand $\mathbf{L} 4(\mathrm{pH}=7)$ and $\mathrm{CuSO}_{4}$ at $298 \mathrm{~K}$, along with its simulation (d). EPR spectrometer settings: microwave frequency, $9.424 \mathrm{GHz}$; microwave power, $10.01 \mathrm{~mW}$; center field, $329.7 \mathrm{mT}$; gain, $2.0 \times 10^{5}$; modulation amplitude, $0.2 \mathrm{mT}$; scan, $42 \mathrm{~s}$; time constant, $10.24 \mathrm{~ms}$; number of scans 25 . The spin-Hamiltonian parameters elucidated from the simulations are summarized in Table 2.

As described above, the EPR spectra obtained by mixing the equimolar aqueous solutions of proligand $\mathbf{L} 4$ and $\mathrm{CuSO}_{4}$ are fully compatible with those measured for $\mathbf{4}$ in aqueous solutions (Figure 3c,d). The formation of 1:1 $\mathrm{Cu}$ (II)-to-ligand complexes in aqueous solutions $\mathbf{L 1}-\mathbf{L 4} / \mathrm{Cu}$ (II) have been previously observed by UV-Vis spectroscopy [28]. Analogous behavior was confirmed also in our study using buffered $(\mathrm{pH}=7)$ proligand solutions. Figure 4 summarizes the UV-Vis spectra measured in the aqueous solutions of $\mathrm{Cu}(\mathrm{II})$ complexes 1 and 4, along with the electronic spectra found by mixing $\mathrm{CuSO}_{4}$ with $\mathbf{~ L 1}$ or $\mathbf{L 4}$. All absorption maxima of $\mathbf{L 1} / \mathrm{CuSO}_{4}$ and $\mathbf{1}(253 \mathrm{~nm}, 313 \mathrm{~nm}$ and $368 \mathrm{~nm})$ as well as $\mathbf{L} 4 / \mathrm{CuSO}_{4}$ and 4 $(237 \mathrm{~nm}, 262 \mathrm{~nm}, 320 \mathrm{~nm}$ and $380 \mathrm{~nm})$, along with a broad low-intensity $\mathrm{d}-\mathrm{d}$ transition maximum around $600 \mathrm{~nm}$, are located at the same positions and possess comparable intensities. This is evidence for the presence of identical 1:1 $\mathrm{Cu}$ (II)-to-ligand complexes in aqueous solutions. The addition of $\mathrm{Cu}$ (II) ions to the buffered proligand solutions led to the formation of the corresponding 1:1 complex with the characteristic absorption band $\left(\lambda_{\max } \sim 375 \mathrm{~nm}\right.$ ), followed by a negligible intensity decrease in time (60-min period, data not shown), most probably reflecting the equilibrium balance at the given $\mathrm{pH}$ as previously described [28]. 
With the aim to investigate the photoinduced generation of reactive oxygen species upon UVA photoexcitation of $\mathrm{Cu}$ (II) complexes 1-4, which may improve their cytotoxic action, the changes in the electronic spectra of these complexes upon steady-state exposure, using a monochromatic UVA radiation source $\left(\lambda_{\max }=365 \mathrm{~nm}\right)$, were monitored. Only small variations were found in the electronic spectra during exposure of $\mathrm{Cu}$ (II) complexes 1-4 dissolved in water, as well as upon irradiation of aqueous solutions prepared by mixing $\mathbf{~} \mathbf{1}-\mathbf{L} 4 / \mathrm{CuSO}_{4}$ (Figure 4). The analogous photostability of 1-4 was confirmed also in DMSO solutions upon UVA photoexcitation as illustrated in Figure 5a for complex 4, in contrast to a significant photoinduced transformation of the proligand L4, which occurred under identical experimental conditions (Figure 5b). Moreover, the results of the EPR spin trapping experiments with DMPO in water, or DMSO, evidenced only very limited generation of ROS upon in situ irradiation of 1-4 (data not shown). We suppose that the presence of $\mathrm{Cu}(\mathrm{II})$ ions causes the quenching of the excited states of the complexes 1-4 [41,42], resulting in a significant decrease of their ability to activate molecular oxygen and produce ROS upon photoexcitation.

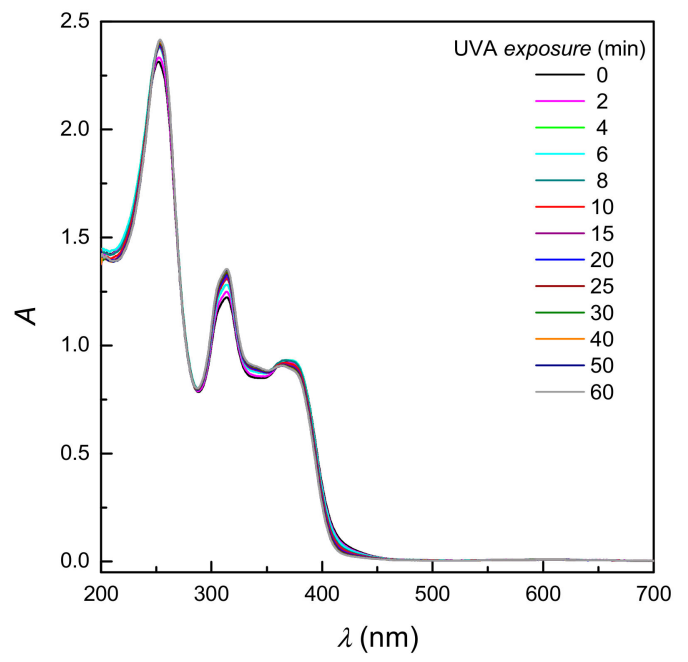

(a)

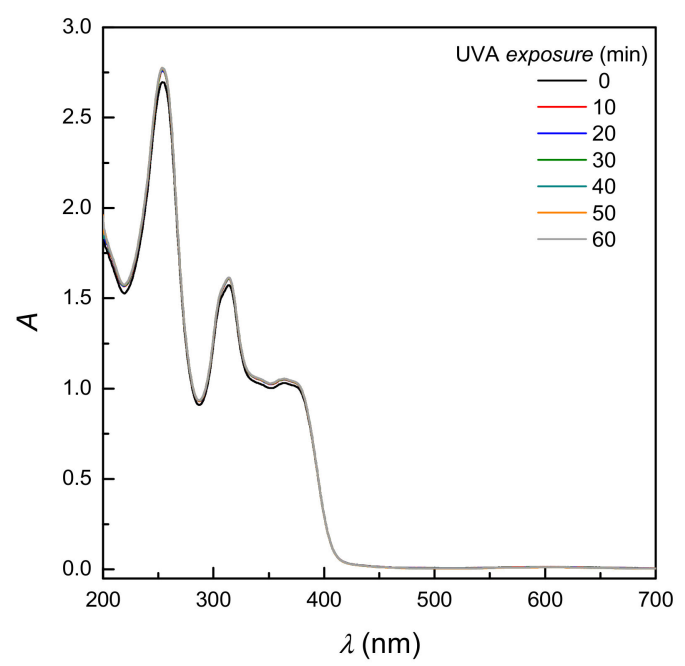

(c)

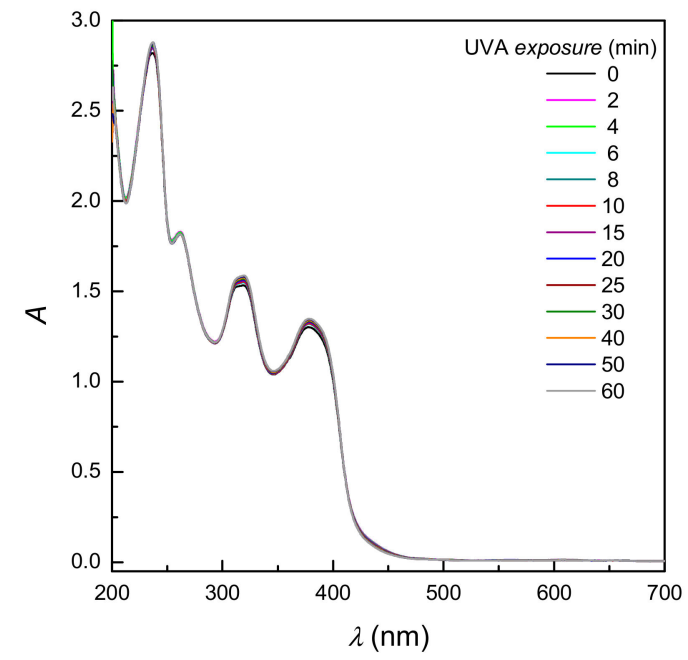

(b)

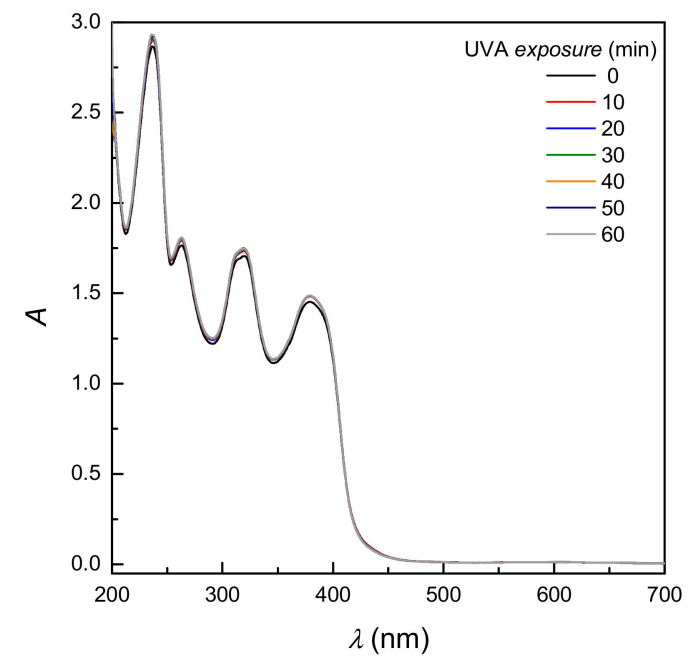

(d)

Figure 4. The electronic absorption spectra of the equimolar mixture $\mathbf{L 1} / \mathrm{CuSO}_{4}(\mathbf{a})$ and $\mathbf{L} 4 / \mathrm{CuSO}_{4}(\mathbf{b})$ in comparison with the spectra of $\mathbf{1}(\mathbf{c})$ and $\mathbf{4}(\mathbf{d})$ in aqueous solutions at $298 \mathrm{~K}$, before and upon discontinuous UVA exposure $\left(\lambda_{\max }=365 \mathrm{~nm}\right.$, irradiance $13 \mathrm{~mW} \mathrm{~cm}^{-2} ; c_{0}(\mathbf{L 1}, \mathbf{L 4})=c_{0}\left(\mathrm{CuSO}_{4}\right)=c_{0}(\mathbf{1}, \mathbf{4})=0.1 \mathrm{mM}$, optical path length $1 \mathrm{~cm}$ ). 


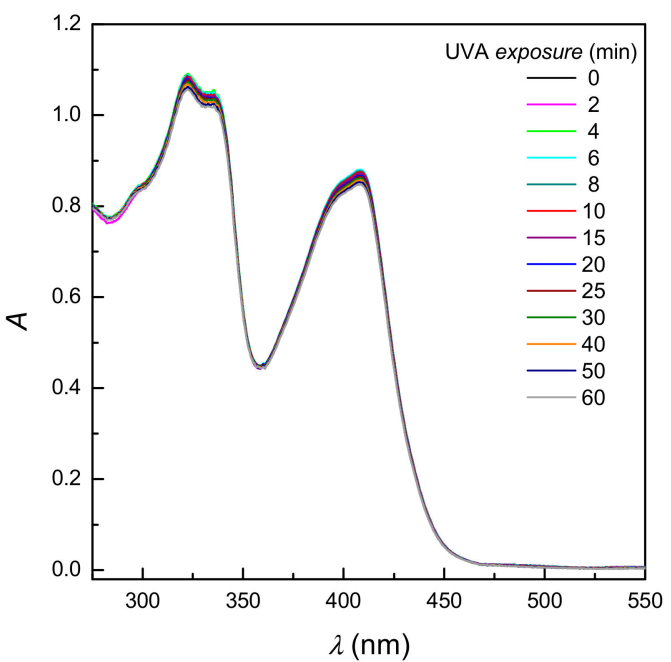

(a)

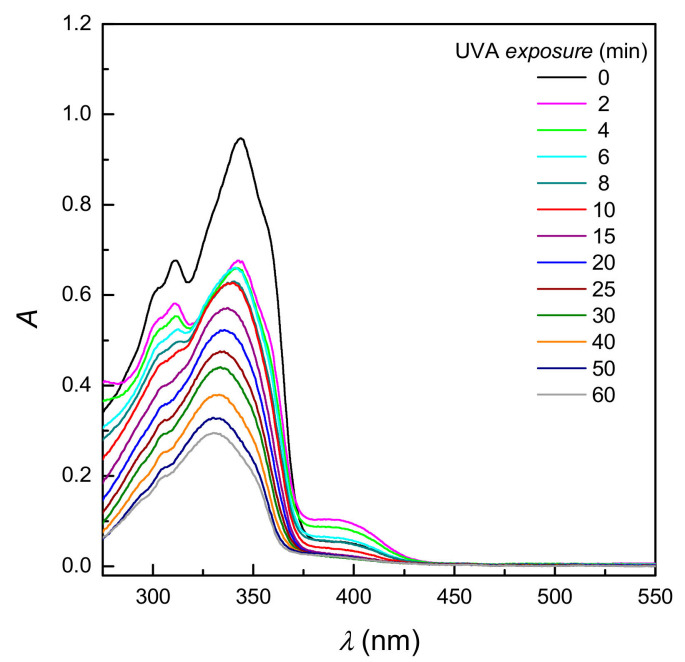

(b)

Figure 5. The changes in the electronic absorption spectra monitored upon discontinuous UVA irradiation $\left(\lambda_{\max }=365 \mathrm{~nm}\right.$, irradiance $\left.13 \mathrm{~mW} \mathrm{~cm}^{-2}\right)$ of $0.1 \mathrm{mM} \mathrm{DMSO}$ solutions of 4 (a) and L4 (b)). Optical path length $1 \mathrm{~cm}$, temperature $298 \mathrm{~K}$.

Our previous experiments with $\mathrm{Cu}(\mathrm{II})$ complexes 1-4 showed a moderate anticancer activity towards human cancer cell lines coupled with a marked ROS accumulation. Hydrogen peroxide is now accepted as a normal metabolite of oxygen in the aerobic metabolism of cells and tissues [43,44], and its interaction with $\mathrm{Cu}$ (II) ions can result in the generation of highly reactive and damaging intermediates $[45,46]$. A simplified redox behavior of the $\mathrm{Cu}(\mathrm{II})$ ion in the reaction with hydrogen peroxide is summarized in Equations (1)-(8), considering the existence of copper ions in the oxidation states $+1,+2$ and +3 [47]:

$$
\begin{gathered}
\mathrm{Cu}(\mathrm{II})+\mathrm{H}_{2} \mathrm{O}_{2} \stackrel{k=461 \mathrm{M}^{-1} \mathrm{~s}^{-1}}{\longrightarrow} \mathrm{Cu}(\mathrm{I})+2 \mathrm{H}^{+}+\mathrm{O}_{2}^{\bullet-} \\
\mathrm{Cu}(\mathrm{I})+\mathrm{H}_{2} \mathrm{O}_{2} \stackrel{k=4.5 \times 10^{5} \mathrm{M}^{-1} \mathrm{~s}^{-1}}{\longrightarrow} \mathrm{Cu}(\mathrm{II})+\mathrm{OH}^{-}+\cdot{ }^{\bullet} \mathrm{OH} \\
\mathrm{Cu}(\mathrm{I})+\mathrm{H}_{2} \mathrm{O}_{2} \stackrel{k=61 \mathrm{M}^{-1} \mathrm{~s}^{-1}}{\longrightarrow} \mathrm{Cu}(\mathrm{III})+2 \mathrm{OH}^{-} \\
\mathrm{Cu}(\mathrm{III})+\mathrm{H}_{2} \mathrm{O}_{2} \stackrel{k=1.3 \times 10^{5} \mathrm{M}^{-1} \mathrm{~s}^{-1}}{\rightleftharpoons} \mathrm{Cu}(\mathrm{II})+2 \mathrm{H}^{+}+\mathrm{O}_{2}^{\bullet-} \\
\mathrm{Cu}(\mathrm{I})+2 \mathrm{H}^{+}+\mathrm{O}_{2}^{\bullet-} \stackrel{k=2 \times 10^{9} \mathrm{M}^{-1} \mathrm{~s}^{-1}}{\longrightarrow} \mathrm{Cu}(\mathrm{II})+\mathrm{H}_{2} \mathrm{O}_{2} \\
\mathrm{Cu}(\mathrm{II})+\mathrm{O}_{2}^{\bullet-} \stackrel{k=1.5 \mathrm{M}^{-1} \mathrm{~s}^{-1}}{\longrightarrow} \mathrm{Cu}(\mathrm{I})+\mathrm{O}_{2} \\
\mathrm{Cu}(\mathrm{I})+\mathrm{O}_{2} \stackrel{k=6.6 \times 10^{8} \mathrm{M}^{-1} \mathrm{~s}^{-1}}{\longrightarrow} \mathrm{Cu}(\mathrm{II})+\mathrm{O}_{2}^{\bullet-} \\
\mathrm{Cu}(\mathrm{I})+\mathrm{Cu}(\mathrm{III}) \stackrel{k=3.5 \times 10^{9} \mathrm{M}^{-1} \mathrm{~s}^{-1}}{\longrightarrow} 2 \mathrm{Cu}(\mathrm{II})
\end{gathered}
$$

In order to follow the potential interaction of hydrogen peroxide with $\mathrm{Cu}(\mathrm{II})$ complexes 1-4, coupled with ROS generation, EPR spin trapping experiments using DMPO spin trap were performed. The addition of hydrogen peroxide to the aqueous solutions of $\mathbf{1 - 4}$, containing DMPO, led to the appearance of a four-line EPR signal characterized by the spin-Hamiltonian parameters $A_{\mathrm{N}}=1.485 \mathrm{mT}$, $A_{\mathrm{H}}{ }^{\beta}=1.480 \mathrm{mT}$ and $g=2.0057$, unambiguously assigned to ${ }^{\circ} \mathrm{DMPO}-\mathrm{OH}$ spin-adduct $[48,49]$. Figure $6 \mathrm{a}$ depicts the EPR spectrum of ${ }^{-D M P O-O H}$ spin-adduct monitored in an aerated aqueous solution of $\mathbf{2}$, in the presence $\mathrm{H}_{2} \mathrm{O}_{2}$ and DMPO. The EPR signal intensity of ${ }^{\bullet} \mathrm{DMPO}-\mathrm{OH}$ increased proportionally 
with the increased initial concentration of $\mathrm{H}_{2} \mathrm{O}_{2}$, which was added into the experimental system with fixed concentrations of 1-4 complexes. This increase in signal intensity evidences a complicated reaction mechanism of hydroxyl radical generation (Equations (1)-(8)). The exact mechanisms of the reactions proceeding in our system cannot be determined, but the EPR experiments with $\mathrm{H}_{2} \mathrm{O}_{2}$ confirmed the formation of the hydroxyl radical spin-adduct only in the solutions of $\mathrm{Cu}$ (II) complexes 1-4. A low-intensity signal of ${ }^{\circ} \mathrm{DMPO}-\mathrm{OH}$ was monitored in the solutions of proligands L1-L4 containing $\mathrm{H}_{2} \mathrm{O}_{2}$ and DMPO (Figure $6 \mathrm{~b}$ ), and was also found in the reference system (i.e., in the aqueous DMPO solution containing $\mathrm{H}_{2} \mathrm{O}_{2}$ ); this reflects the interaction of the reactive spin trap with $\mathrm{H}_{2} \mathrm{O}_{2}$ present at high concentration. The addition of hydrogen peroxide into the aqueous solutions of 1-4 had no effect on the intensity of the EPR signal of paramagnetic $\mathrm{Cu}$ (II) ions, which correlated with rapid transformation of diamagnetic $\mathrm{Cu}(\mathrm{I}) / \mathrm{Cu}(\mathrm{III})$ to $\mathrm{Cu}(\mathrm{II})$ in the aerated $\mathrm{H}_{2} \mathrm{O}_{2}$ solutions [47].

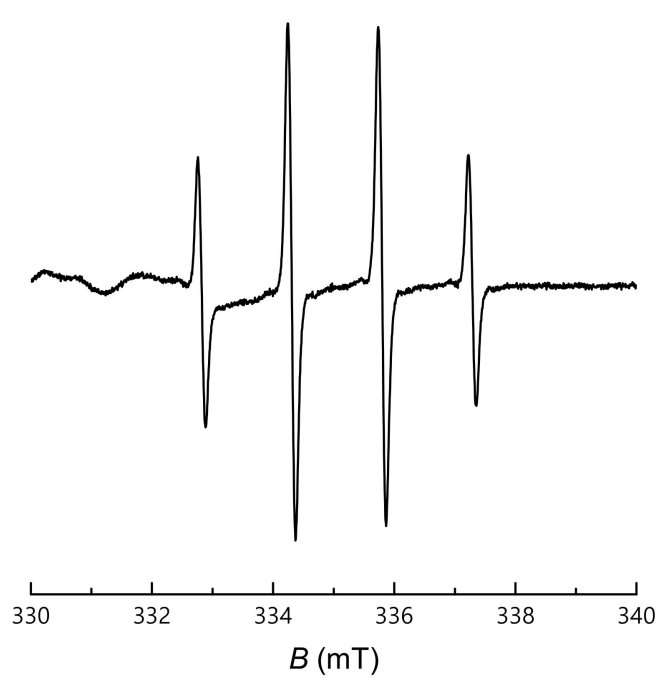

(a)

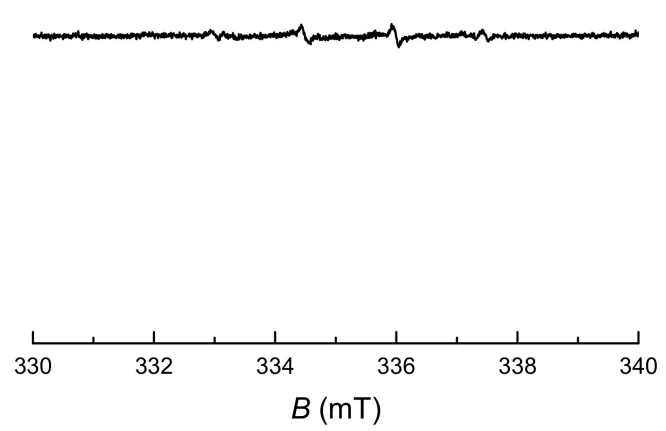

(b)

Figure 6. EPR spectrum of the ${ }^{-D M P O-O H}$ spin-adduct measured at $298 \mathrm{~K}$ in solutions: (a) $2 / \mathrm{H}_{2} \mathrm{O}_{2} / \mathrm{DMPO} / \mathrm{H}_{2} \mathrm{O}$ and (b) $\mathrm{L} 2 / \mathrm{H}_{2} \mathrm{O}_{2} / \mathrm{DMPO} / \mathrm{H}_{2} \mathrm{O}$. Initial concentrations: $c_{0}(2)=0.4 \mathrm{mM}$, $c_{0}(\mathrm{~L} 2)=0.4 \mathrm{mM}, c_{0}\left(\mathrm{H}_{2} \mathrm{O}_{2}\right)=0.4 \mathrm{M}, c_{0}(\mathrm{DMPO})=0.04 \mathrm{M}$. EPR spectrometer settings: microwave frequency, $9.448 \mathrm{GHz}$; microwave power, $10.03 \mathrm{~mW}$; center field, $335.0 \mathrm{mT}$; gain, $2.0 \times 10^{5}$; modulation amplitude, $0.1 \mathrm{mT}$; scan, $42 \mathrm{~s}$; time constant, $10.24 \mathrm{~ms}$; number of scans 30.

\subsection{Photoinduced Processes of Proligands Monitored by the EPR Spin Trapping Technique}

Many pharmaceutically utilized heterocyclic compounds are known to be sensitive towards UVA exposure, which could either increase or inhibit their biological activity. Such photoinduced processes are often related to the generation of reactive oxygen species via the activation of molecular oxygen by the excited states of the photoactive molecule or directly by the molecular changes in the compound itself $[50,51]$. Previously, we studied in detail the photoactivation of molecular oxygen upon excitation of different quinolone derivatives (fluoroquinolones, nitroquinolones, selenadiazoloquinolones), and considerable photobiological effects were found for several derivatives [52-55].

As information regarding the behavior of aromatic thiosemicarbazones upon irradiation is limited [56,57], the ability of proligands L1-L4 to activate oxygen and generate ROS upon their UVA irradiation was investigated in aerated aqueous $(\mathrm{pH}=7)$ or DMSO solutions, using EPR spin trapping with DMPO. Figure 7 shows the experimental and simulated EPR spectra of DMPO spin-adducts obtained upon the UVA exposure of proligand L4 in both solvents. The EPR spectrum measured upon irradiation of the system L4/DMPO/buffer/air consists of two signals. The dominant twelve-line signal of ${ }^{\bullet} \mathrm{DMPO}-\mathrm{OOH}$ with spin-Hamiltonian parameters $A_{\mathrm{N}}=1.417 \mathrm{mT}, A_{\mathrm{H}}{ }^{\beta}=1.197 \mathrm{mT}$, $A_{\mathrm{H}}^{\gamma}=0.118 \mathrm{mT} ; g=2.0058$ [48], is superimposed on the four-line signal typical of a ${ }^{\bullet} \mathrm{DMPO}-\mathrm{OH}$ 
spin-adduct. However, in aqueous systems, the photogenerated $\mathrm{O}_{2}^{\bullet-} /{ }^{\bullet} \mathrm{OOH}$ is readily transformed into $\mathrm{H}_{2} \mathrm{O}_{2}$ [58], which can be involved in the consecutive (photo)reactions producing ${ }^{\bullet} \mathrm{OH}$ [49].

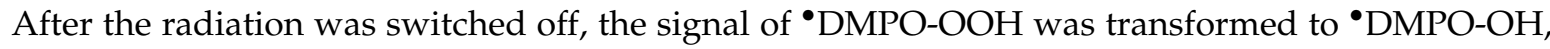
reflecting the well-known behavior and low stability of ${ }^{\circ} \mathrm{DMPO}-\mathrm{OOH}$ in aqueous media [59]. The analogous EPR spectra of DMPO spin-adducts were obtained upon UVA exposure of all proligands L1-L4 in buffer, thus the formation of the ${ }^{\bullet} \mathrm{DMPO}-\mathrm{OOH}$ spin-adduct evidenced the interaction of their photoexcited molecules with molecular oxygen via the electron transfer mechanism [60].

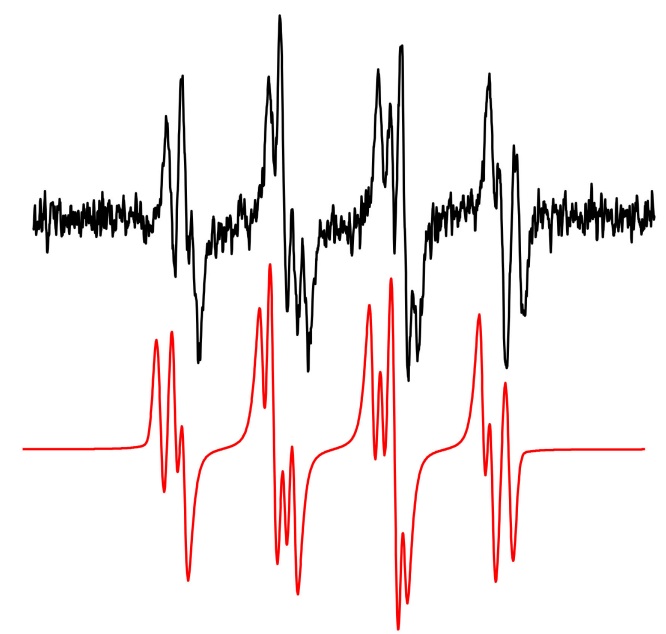

(a)

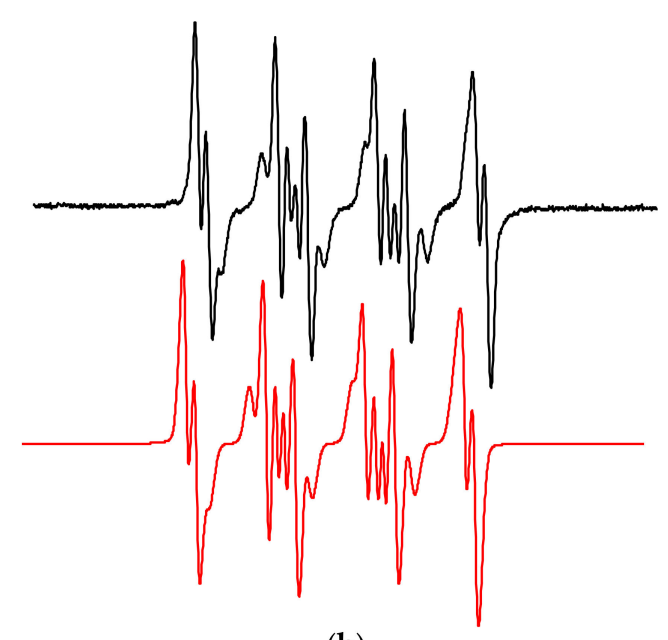

(b)

Figure 7. The experimental (-) and simulated (-) EPR spectra monitored upon in situ UVA exposure of proligand $\mathbf{L} 4$ in the buffered $(\mathrm{pH}=7)(\mathbf{a})$ or DMSO $(\mathbf{b})$ solution, in the presence of a DMPO spin trapping agent. $\left(c_{0}(\mathbf{L} 4)=0.8 \mathrm{mM}, c_{0}(\mathrm{DMPO})=0.04 \mathrm{M}, \lambda_{\max }=365 \mathrm{~nm}\right.$, irradiance $\left.13 \mathrm{~mW} \mathrm{~cm}^{-2}\right)$. EPR spectrometer settings: microwave frequency, 9.458 or $9.434 \mathrm{GHz}$; microwave power, 20.02 or $10.01 \mathrm{~mW}$; center field, $335.2 \mathrm{mT}$; magnetic field sweep, $8 \mathrm{mT}$; gain, $5.02 \times 10^{5}$ or $2.0 \times 10^{5}$; modulation amplitude, 0.1 or $0.05 \mathrm{mT}$; scan, $42 \mathrm{~s}$; time constant, 20.48 or $10.24 \mathrm{~ms}$; number of scans 25 .

The increased stability of the photogenerated superoxide radical anion in aprotic media [58] is well documented by the enhanced intensity of the corresponding spin-adduct EPR signal, measured upon irradiation of solution L4/DMPO/DMSO/air (Figure 7b). The in situ photoactivation of L4 in the aerated DMPO/DMSO solution resulted in the immediate generation of a characteristic twelve-line spectrum with spin-Hamiltonian parameters $\left(A_{\mathrm{N}}=1.275 \mathrm{mT}, A_{\mathrm{H}}{ }^{\beta}=1.033 \mathrm{mT}, A_{\mathrm{H}}^{\gamma}=0.138 \mathrm{mT}\right.$; $g=2.0057$ ), which was fully compatible with the ${ }^{\bullet} \mathrm{DMPO}-\mathrm{O}_{2}{ }^{-}$spin-adduct [48] found as a major component of the solution (relative concentration 66\%). Simulation analysis of the experimental spectrum shown in Figure $7 \mathrm{~b}$ revealed the superoxide radical anion as well as the presence of other paramagnetic species, generated via interaction with DMSO $[49,61]$, trapped as a $\bullet \mathrm{DMPO}^{-\mathrm{OCH}} \mathrm{H}_{3}$ spin-adduct $\left(A_{\mathrm{N}}=1.314 \mathrm{mT}, A_{\mathrm{H}}{ }^{\beta}=0.800 \mathrm{mT}, A_{\mathrm{H}} \gamma=0.167 \mathrm{mT} ; g=2.0057\right.$, relative concentration $\left.34 \%\right)$. The generation of the ${ }^{\bullet} \mathrm{DMPO}^{-} \mathrm{O}_{2}{ }^{-}$spin-adduct monitored upon UVA excitation of L1-L4 in DMSO solutions confirmed the activation of molecular oxygen, via photoexcitated proligand molecules. As mentioned above, the addition of an equimolar concentration of $\mathrm{Cu}(\mathrm{II})$ ions to a proligand solution or dissolved $\mathrm{Cu}(\mathrm{II})$ complexes 1-4 did not yield any DMPO spin-adducts upon exposure and their photoinduced processes were fully inhibited.

\subsection{UVA Photoexcitation of Proligands Monitored by UV-Vis Spectroscopy-Steady-State Experiments}

Thiosemicarbazones represent polyfunctional compounds with the potential to cyclize upon UV irradiation; the reaction depends on conditions used as well as the structure of the precursors $[56,57]$. Previous investigations evidenced that the prolonged UV irradiation of 2-methyl-4-phenyl-substituted 
benzaldehyde thiosemicarbazones yields the corresponding $\Delta^{2}-1,2,4$-triazoline-5-thione derivatives through the formation of stable 1,2,4-triazolidine-5-thione intermediates [57].

The proton dissociation of proligands $\mathbf{L 1}-\mathbf{L} 4$ in their respective aqueous solutions at different $\mathrm{pH}$ values is associated with the characteristic spectral changes in their electronic absorption spectra [28]. The aqueous solutions of L1-L4 are colorless at neutral $\mathrm{pH}$, with the absorption maxima at $240 \mathrm{~nm}$, $300 \mathrm{~nm}$ and $327 \mathrm{~nm}$ (Figure 8), whereas the absorption maxima were at $260 \mathrm{~nm}, 292 \mathrm{~nm}$ and $367 \mathrm{~nm}$ in the alkaline solutions ( $\mathrm{pH}=10$ ) (Figure 9). Proligands L1-L4 showed a limited photostability, as upon UVA irradiation in the buffered solutions the significant changes were monitored in their electronic absorption spectra, which were only slightly dependent on the substituent character at the terminal nitrogen (Figures 8 and 9). The UVA photoexcitation of proligands L1-L4 at neutral $\mathbf{p H}$ resulted in a substantial absorbance decrease at 300 and $327 \mathrm{~nm}$ within $60 \mathrm{~min}$. This is typical for aldimine and phenolic chromophores [28] (Figure 8), reflecting their phototransformation. As the EPR spin trapping experiments confirmed the photogeneration of $\mathrm{O}_{2}{ }^{\bullet-} / \bullet \mathrm{OOH}$ and hydroxyl radicals under analogous experimental conditions, we can suppose that the observed damage of the aldimine and phenolic chromophores was induced by the radical attack via photogenerated ROS.

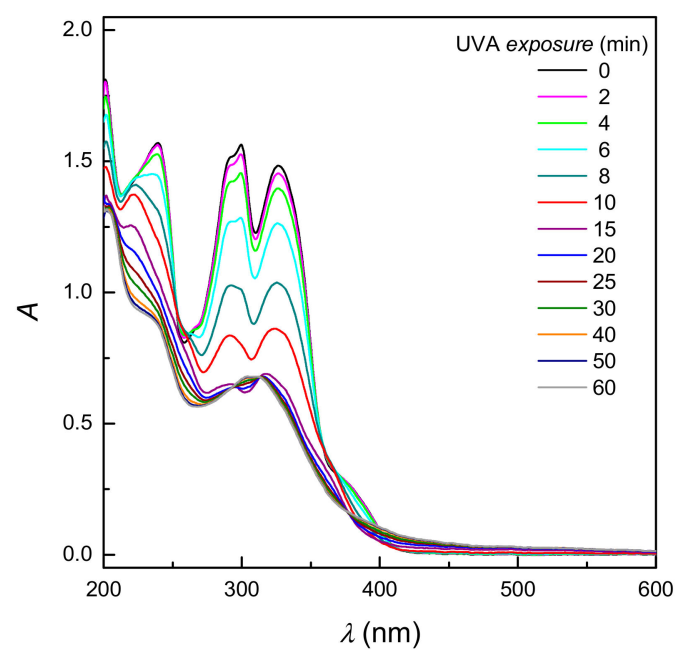

(a)

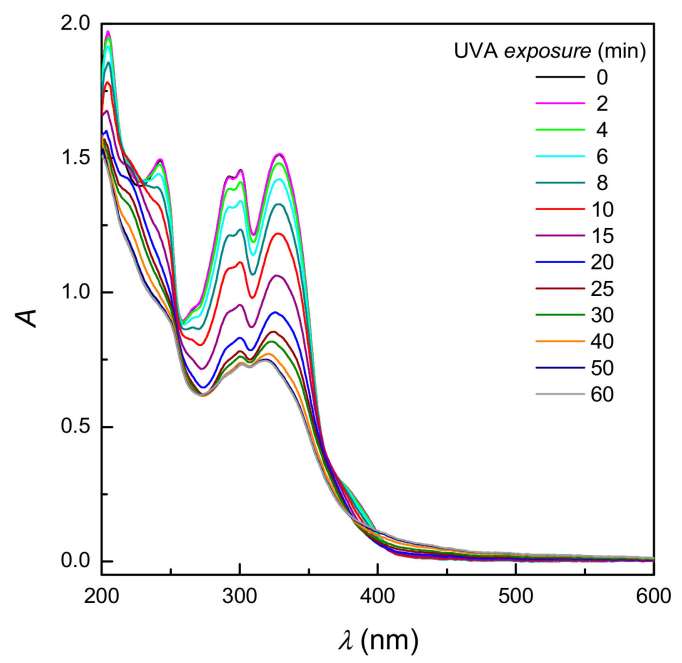

(c)

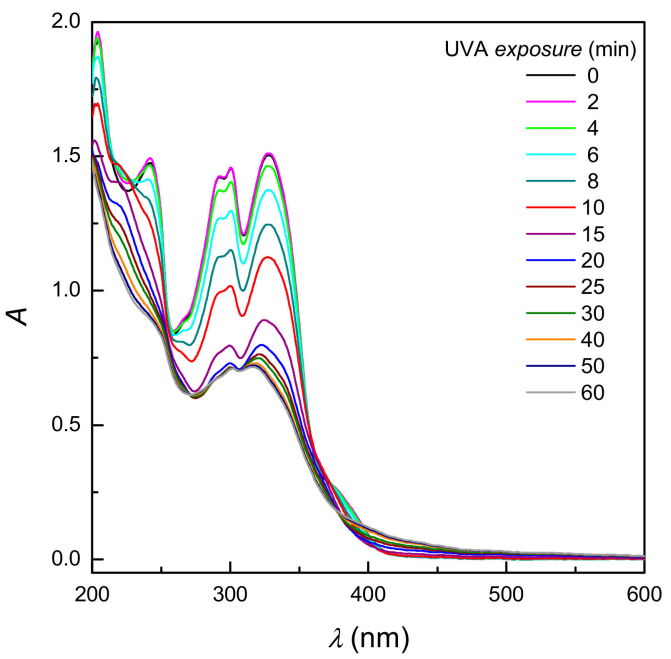

(b)

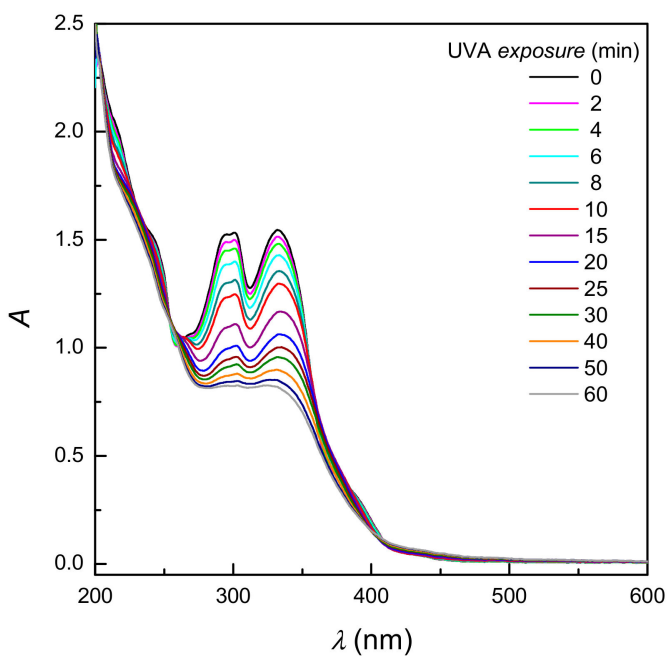

(d)

Figure 8. The changes in the electronic absorption spectra monitored upon discontinuous UVA irradiation $\left(\lambda_{\max }=365 \mathrm{~nm}\right.$, irradiance $\left.13 \mathrm{~mW} \mathrm{~cm}^{-2}\right)$ investigating $0.1 \mathrm{mM}$ buffer solutions $(\mathrm{pH}=7)$ of proligand L1 (a), L2 (b), L3 (c) and L4 (d). Optical path length $1 \mathrm{~cm}$, temperature $298 \mathrm{~K}$. 
The intensive absorption band at $370 \mathrm{~nm}$ was found in the electronic spectra in alkaline solutions $(\mathrm{pH}=10)$ due to the deprotonation of the phenolic group of proligands $\mathbf{L} \mathbf{1}-\mathbf{L} 4$, reflecting the presence of an extended $\pi$-conjugated system [28]. Photoexcitation of proligand molecules L1-L4 with UVA radiation $\left(\lambda_{\max }=365 \mathrm{~nm}\right)$ resulted in a substantial decrease in the absorption bands at $250 \mathrm{~nm}, 300 \mathrm{~nm}$, and $370 \mathrm{~nm}$ under aforementioned experimental conditions. The decrease was also associated with the formation of a low-intensity absorption band at $\sim 550 \mathrm{~nm}$, visible especially for proligand L1 with hydrogen at the terminal nitrogen (Figure 9). The limited photostability of all proligands upon UVA exposure was also monitored in aprotic DMSO, revealing the decline in the absorption band at $345 \mathrm{~nm}$ as is shown for $\mathbf{L} 4$ in Figure $5 b$.

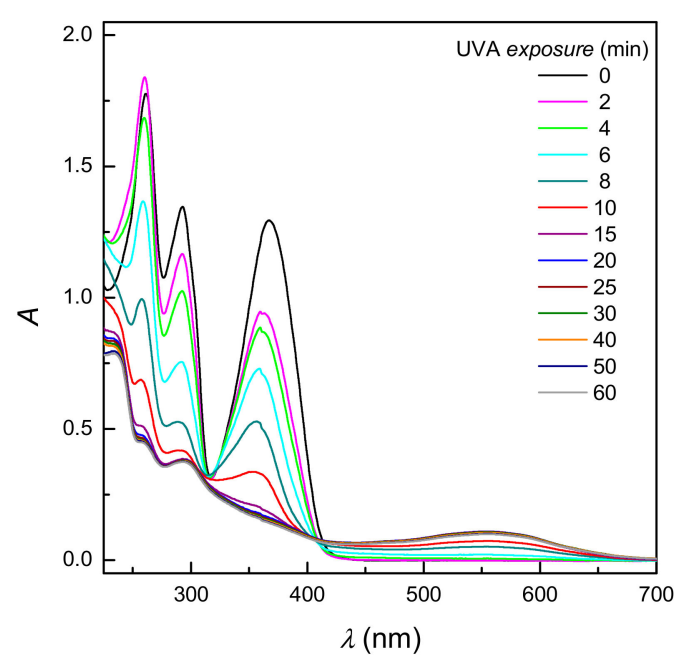

(a)

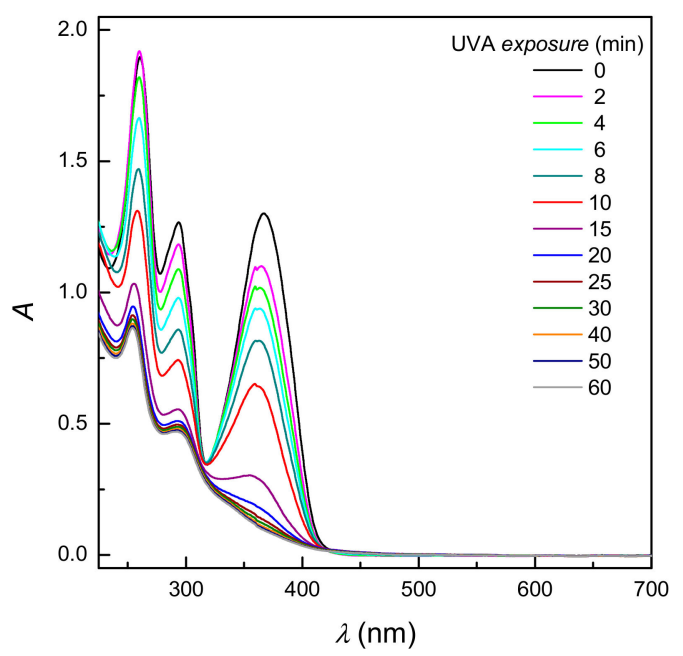

(c)

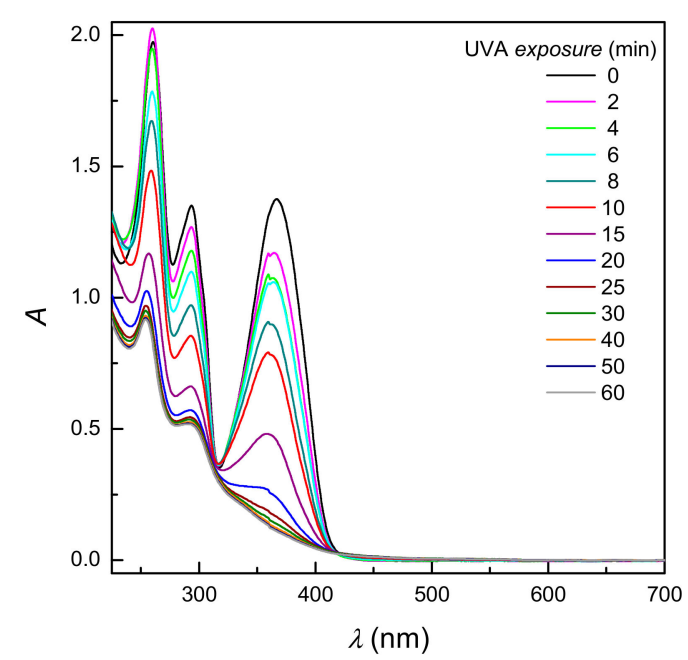

(b)

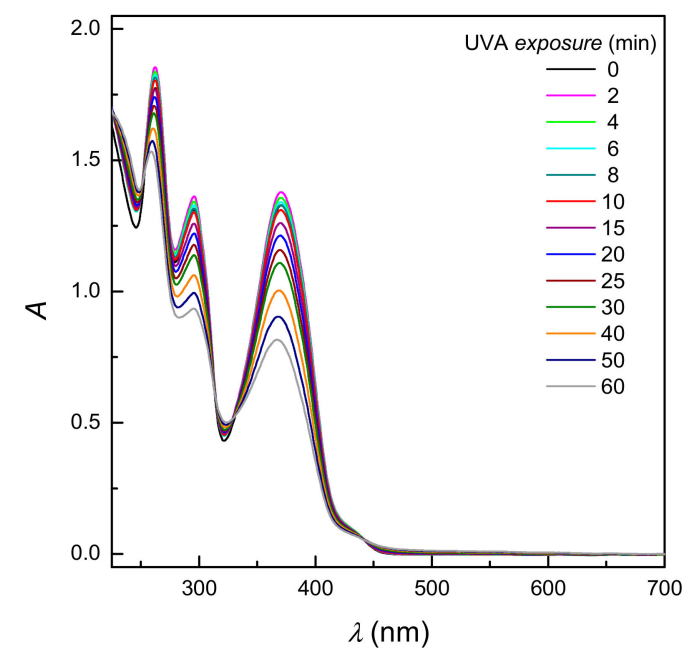

(d)

Figure 9. The changes in the electronic absorption spectra monitored upon discontinuous UVA irradiation $\left(\lambda_{\max }=365 \mathrm{~nm}\right.$, irradiance $\left.13 \mathrm{~mW} \mathrm{~cm}^{-2}\right)$ investigating $0.1 \mathrm{mM}$ buffer solutions $(\mathrm{pH}=10)$ of proligand L1 (a), L2 (b), L3 (c) and L4 (d). Optical path length $1 \mathrm{~cm}$, temperature $298 \mathrm{~K}$.

The results of EPR spin trapping experiments and the changes monitored in the electronic absorption spectra of proligands L1-L4 upon UVA exposure confirmed the photoinduced generation of ROS via photoactivation of molecular oxygen and a limited photostability of the proligands in aqueous and DMSO solutions. 


\section{Materials and Methods}

All reagents were used as purchased from commercial suppliers, mainly Sigma Aldrich (Buchs, Switzerland). The 5-sulfonate-salicylaldehyde sodium salts $\left(\mathrm{NaH}_{2} \mathrm{~L}^{\mathrm{X}} ; \mathrm{X}=\mathrm{H}, \mathrm{Me}, \mathrm{Et}, \mathrm{Ph}\right.$; L1-L4 in Scheme 1) and their $\mathrm{Cu}(\mathrm{II})$-complexes $\left(\mathrm{Cu}^{\mathrm{II}} \mathrm{HL}^{\mathrm{X}}(\mathrm{Y}) ; \mathrm{X}=\mathrm{H}, \mathrm{Me}, \mathrm{Et}, \mathrm{Ph} ; \mathrm{Y}=\mathrm{DMSO}, \mathrm{H}_{2} \mathrm{O}\right.$; 1-4 in Scheme 1) were prepared by previously described procedures [28]. The spin trapping agent 5,5-dimethyl-1-pyrroline N-oxide (DMPO; Sigma-Aldrich, Buchs, Switzerland) was distilled prior to the application. Hydrogen peroxide ( $\geq 30 \%$, for trace analysis) was purchased from Sigma-Aldrich and used without further purification.

The solid-state EPR experiments at room temperature and at $100 \mathrm{~K}$ were performed by an EMX Plus EPR spectrometer (Bruker, Rheinstetten, Germany) operating in Q-band in the standard ER 5106 QT Q-band probe for cw-EPR, and by an EMX EPR spectrometer (Bruker, Rheinstetten, Germany), operating in X-band at $100 \mathrm{kHz}$ field modulation in the standard TE $\mathrm{T}_{102}$ (ER $4102 \mathrm{ST}$ ) rectangular cavity. Thin-walled quartz EPR tubes (Bruker) were used in all solid-state experiments. The temperature was lowered to $100 \mathrm{~K}$ by the temperature control unit ER 4141VT-U (Q-band; Bruker) or ER 4111 VT (X-band; Bruker), with liquid nitrogen. The $g$-values were determined by the simultaneous measurement of a reference sample containing $\mathrm{Mn}(\mathrm{II}) / \mathrm{MgO}$ standard, a standard strong pitch (Bruker) placed on the wall of the EPR cell or using a nuclear magnetic resonance teslameter (ER 036TM, Bruker, Rheinstetten, Germany) and integrated frequency counter. The effect of temperature on the EPR spectra of Cu(II) complexes 1-4 in the aqueous or DMSO solution was monitored over the temperature range 298-348 K; a Bruker temperature control unit ER 4111 VT was used to adjust the temperature. The experimental EPR spectra were processed and analyzed by the Bruker software WinEPR, and the simulated spectra were calculated using the SimFonia program (Bruker) or EasySpin 5.1.10 simulation toolbox [62] working under Matlab (MathWorks, Natick, MA, USA) software.

The generation of paramagnetic intermediates was monitored by cw-EPR spectroscopy using the EMX spectrometer. Freshly prepared $1 \mathrm{mM}$ solutions of $\mathrm{Cu}(\mathrm{II})$ complexes $\mathbf{1}-\mathbf{4}$ or proligands L1-L4 were mixed with the solution of spin trapping agent DMPO before the EPR measurements, carefully aerated and immediately transferred to a flat quartz cell (WG 808-Q, Wilmad-LabGlass, Vineland, NJ, USA). The samples were irradiated at $298 \mathrm{~K}$ directly in ER 4102 ST cavity and the EPR spectra were measured in situ. The UV LED monochromatic radiator $\left(\lambda_{\max }=365 \mathrm{~nm}\right.$, irradiance $13 \mathrm{~mW}$ $\mathrm{cm}^{-2}$; Bluepoint LED, Hönle UV Technology, Gräfelfing/München, Germany) was used as the source of monochromatic UVA light. The experimental EPR spectra of spin-adducts were simulated using Winsim2002 software (NIEHS, Durham, NC, USA) suitable for analysis and fitting of multi-component isotropic EPR spectra of nitroxide radicals [63].

The UV-Vis spectra of thiosemicarbazone $\mathrm{Cu}(\mathrm{II})$ complexes 1-4 and proligands L1-L4 were measured on a UV-3600 UV/vis/NIR (Shimadzu, Kyoto, Japan) spectrophotometer at 298 K. A cell holder (TCC-240A, Shimadzu) was used to control the temperature. The sets of steady-state experiments were performed to monitor the changes in the electronic absorption spectra upon discontinuous irradiation in aqueous or DMSO solutions. The stock solutions $(1 \mathrm{mM})$ were prepared directly before measurements in deionized water, buffer solutions or dried DMSO (SeccoSolv, Merck, Darmstadt, Germany) and diluted to the final concentration of $0.1 \mathrm{mM}$. As-prepared solutions were irradiated in a 1-cm rectangular quartz cell (Agilent Technologies, Santa Clara, CA, USA) using a monochromatic LED source $\left(\lambda_{\max }=365 \mathrm{~nm}\right.$, irradiance $13 \mathrm{~mW} \mathrm{~cm}^{-2}$; Bluepoint LED) under the atmospheric conditions. The first spectrum was measured without irradiation; the following spectra were recorded immediately after a defined exposure, until the total irradiation time of 60 min was reached. The spectra acquisition was performed using UV Probe (Shimadzu, Kyoto, Japan) software and processed by OriginPro (OriginLab, Northampton, MA, USA) program. The pH values of solutions were measured by a Jenway 3520 pH Meter (Jenway, Stone, Staffordshire, UK) using a glass combination pH electrode (Sentek P13, Essex, UK); Jenway pH buffers ( $\mathrm{pH} 4,7$ and 9) were used for calibration. 


\section{Conclusions}

EPR spin trapping experiments showed that, upon UVA exposure, the proligands L1-L4 behave as photosensitizers generating the superoxide radical anion and hydroxyl radical via photoactivation of molecular oxygen. Addition of an equimolar amount of $\mathrm{Cu}(\mathrm{II})$ ions into the aqueous proligand solutions resulted in 1:1 complex formation through the ONS-donor set, with the EPR and electronic absorption spectra fully compatible with those found for the solutions of corresponding $\mathrm{Cu}(\mathrm{II})$ complexes 1-4. The photoactivation of molecular oxygen and ROS generation is significantly hindered upon UVA photoexcitation of $\mathrm{Cu}$ (II) complexes. However, the dark redox activity of the $\mathrm{Cu}$ (II) central ion with hydrogen peroxide resulted in the formation of hydroxyl radicals, detected as the corresponding $\bullet \mathrm{DMPO}-\mathrm{OH}$ spin-adduct.

Acknowledgments: This work was supported by the Slovak Research and Development Agency under the contract No. APVV-15-0053 and the Scientific Grant Agency of the Slovak Republic (Projects VEGA/1/0026/18, VEGA1/0686/17) and by Austrian Science Fund (Project No. P28223-N34). The authors gratefully acknowledge Zuzana Barbieriková, Peter Rapta and Michael K. Lawson for fruitful discussion and constructive comments.

Author Contributions: V.B.A., A.S. and O.P. prepared the samples. M.H., M.M. and V.B. performed the experiments, analyzed the data and wrote the paper.

Conflicts of Interest: The authors declare no conflict of interest.

\section{References}

1. Beraldo, H.; Gambino, D. The wide pharmacological versatility of semicarbazones, thiosemicarbozones and their metal complexes. Mini-Rev. Med. Chem. 2004, 4, 31-39. [CrossRef] [PubMed]

2. Yu, Y.; Kalinowski, D.S.; Kovacevic, Z.; Siafakas, A.R.; Jansson, P.J.; Stefani, C.; Lovejoy, D.B.; Sharpe, P.C.; Bernhardt, P.V.; Richardson, D.R. Thiosemicarbazones from the old to new: Iron chelators that are more than just ribonucleotide reductase inhibitors. J. Med. Chem. 2009, 52, 5271-5294. [CrossRef] [PubMed]

3. Lobana, T.S.; Sharma, R.; Bawa, G.; Khanna, S. Bonding and structure trends of thiosemicarbazone derivatives of metals-an overview. Coord. Chem. Rev. 2009, 253, 977-1055. [CrossRef]

4. Kalinowski, D.S.; Quach, P.; Richardson, D.R. Thiosemicarbazones: The new wave in cancer treatment. Future Med. Chem. 2009, 1, 1143-1151. [CrossRef] [PubMed]

5. West, D.X.; Liberta, A.E.; Padhye, S.B.; Chikate, R.C.; Sonawane, P.B.; Kumbhar, A.S.; Yerande, R.G. Thiosemicarbazone complexes of copper(II): Structural and biological studies. Coord. Chem. Rev. 1993, 123, 49-71. [CrossRef]

6. Padhyé, S.; Kauffman, G.B. Transition metal complexes of semicarbazones and thiosemicarbazones. Coord. Chem. Rev. 1985, 63, 127-160. [CrossRef]

7. Pahontu, E.; Fala, V.; Gulea, A.; Poirier, D.; Tapcov, V.; Rosu, T. Synthesis and characterization of some new $\mathrm{Cu}(\mathrm{II}), \mathrm{Ni}(\mathrm{II})$ and $\mathrm{Zn}(\mathrm{II})$ complexes with salicylidene thiosemicarbazones: Antibacterial, antifungal and in vitro antileukemia activity. Molecules 2013, 18, 8812-8836. [CrossRef] [PubMed]

8. Reis, D.C.; Despaigne, A.A.R.; Da Silva, J.G.; Silva, N.F.; Vilela, C.F.; Mendes, I.C.; Takahashi, J.A.; Beraldo, H. Structural studies and investigation on the activity of imidazole-derived thiosemicarbazones and hydrazones against crop-related fungi. Molecules 2013, 18, 12645-12662. [CrossRef] [PubMed]

9. Serda, M.; Anna, M.W.; Jampilek, J.; Pesko, M.; Kralova, K.; Vejsova, M.; Musiol, R.; Ratuszna, A.; Polanski, J. Investigation of the biological properties of (hetero)aromatic thiosemicarbazones. Molecules 2012, 17, 13483-13502. [CrossRef] [PubMed]

10. Park, K.C.; Fouani, L.; Jansson, P.J.; Wooi, D.; Sahni, S.; Lane, D.J.R.; Palanimuthu, D.; Lok, H.C.; Kovačević, Z.; Huang, M.L.H.; et al. Copper and conquer: Copper complexes of di-2-pyridylketone thiosemicarbazones as novel anti-cancer therapeutics. Metallomics 2016, 8, 874-886. [CrossRef] [PubMed]

11. Pelosi, G.; Bisceglie, F.; Bignami, F.; Ronzi, P.; Schiavone, P.; Re, M.C.; Casoli, C.; Pilotti, E. Antiretroviral activity of thiosemicarbazone metal complexes. J. Med. Chem. 2010, 53, 8765-8769. [CrossRef] [PubMed]

12. Rogolino, D.; Gatti, A.; Carcelli, M.; Pelosi, G.; Bisceglie, F.; Restivo, F.M.; Degola, F.; Buschini, A.; Montalbano, S.; Feretti, D.; et al. Thiosemicarbazone scaffold for the design of antifungal and antiaflatoxigenic agents: Evaluation of ligands and related copper complexes. Sci. Rep. 2017, 7. [CrossRef] [PubMed] 
13. Palanimuthu, D.; Poon, R.; Sahni, S.; Anjum, R.; Hibbs, D.; Lin, H.Y.; Bernhardt, P.V.; Kalinowski, D.S.; Richardson, D.R. A novel class of thiosemicarbazones show multi-functional activity for the treatment of Alzheimer's disease. Eur. J. Med. Chem. 2017, 139, 612-632. [CrossRef] [PubMed]

14. Rogolino, D.; Cavazzoni, A.; Gatti, A.; Tegoni, M.; Pelosi, G.; Verdolino, V.; Fumarola, C.; Cretella, D.; Petronini, P.G.; Carcelli, M. Anti-proliferative effects of copper(II) complexes with hydroxyquinoline-thiosemicarbazone ligands. Eur. J. Med. Chem. 2017, 128, 140-153. [CrossRef] [PubMed]

15. Venkatachalam, T.K.; Bernhardt, P.V.; Noble, C.J.; Fletcher, N.; Pierens, G.K.; Thurecht, K.J.; Reutens, D.C. Synthesis, characterization and biological activities of semicarbazones and their copper complexes. J. Inorg. Biochem. 2016, 162, 295-308. [CrossRef] [PubMed]

16. Kowol, C.R.; Heffeter, P.; Miklos, W.; Gille, L.; Trondl, R.; Cappellacci, L.; Berger, W.; Keppler, B.K. Mechanisms underlying reductant-induced reactive oxygen species formation by anticancer copper(II) compounds. J. Biol. Inorg. Chem. 2012, 17, 409-423. [CrossRef] [PubMed]

17. Popović-Bijelić, A.; Kowol, C.R.; Lind, M.E.S.; Luo, J.; Himo, F.; Enyedy, E.A.; Arion, V.B.; Gräslund, A. Ribonucleotide reductase inhibition by metal complexes of triapine (3-aminopyridine-2-carboxaldehyde thiosemicarbazone): A combined experimental and theoretical study. J. Inorg. Biochem. 2011, 105, 1422-1431. [CrossRef] [PubMed]

18. Zaltariov, M.F.; Hammerstad, M.; Arabshahi, H.J.; Jovanović, K.; Richter, K.W.; Cazacu, M.; Shova, S.; Balan, M.; Andersen, N.H.; Radulović, S.; et al. New iminodiacetate-thiosemicarbazone hybrids and their copper(II) complexes are potential ribonucleotide reductase R2 inhibitors with high antiproliferative activity. Inorg. Chem. 2017, 56, 3532-3549. [CrossRef] [PubMed]

19. López-Torres, E.; Mendiola, M.A.; Pastor, C.J.; Souto Pérez, B. Versatile chelating behavior of benzil bis(thiosemicarbazone) in zinc, cadmium, and nickel complexes. Inorg. Chem. 2004, 43, 5222-5230. [CrossRef] [PubMed]

20. Lobana, T.S.; Khanna, S.; Hundal, G.; Butcher, R.J.; Castineiras, A. Mono- and di-nuclear complexes of thiosemicarbazones with copper(I): Synthesis, spectroscopy and structures. Polyhedron 2009, 28, 3899-3906. [CrossRef]

21. Pedrido, R.; González-Noya, A.M.; Romero, M.J.; Martínez-Calvo, M.; Vázquez López, M.; Gómez-Fórneas, E.; Zaragoza, G.; Bermejo, M.R. Pentadentate thiosemicarbazones as versatile chelating systems. A comparative structural study of their metallic complexes. Dalton Trans. 2008, 6776-6787. [CrossRef] [PubMed]

22. Milunovic, M.N.M.; Enyedy, É.A.; Nagy, N.V.; Kiss, T.; Trondl, R.; Jakupec, M.A.; Keppler, B.K.; Krachler, R.; Novitchi, G.; Arion, V.B. L- and D-proline thiosemicarbazone conjugates: Coordination behavior in solution and the effect of copper(II) coordination on their antiproliferative activity. Inorg. Chem. 2012, 51, 9309-9321. [CrossRef] [PubMed]

23. Bacher, F.; Enyedy, E.A.; Nagy, N.V.; Rockenbauer, A.; Bognár, G.M.; Trondl, R.; Novak, M.S.; Klapproth, E.; Kiss, T.; Arion, V.B. Copper(II) complexes with highly water-soluble L- and D-proline- thiosemicarbazone conjugates as potential inhibitors of topoisomerase ii $\alpha$. Inorg. Chem. 2013, 52, 8895-8908. [CrossRef] [PubMed]

24. Bacher, F.; Dömötör, O.; Enyedy, É.A.; Filipović, L.; Radulović, S.; Smith, G.S.; Arion, V.B. Complex formation reactions of gallium(III) and iron(III/II) with L-proline-thiosemicarbazone hybrids: A comparative study. Inorg. Chim. Acta 2017, 455, 505-513. [CrossRef]

25. Dobrova, A.; Platzer, S.; Bacher, F.; Milunovic, M.N.M.; Dobrov, A.; Spengler, G.; Enyedy, É.A.; Novitchi, G.; Arion, V.B. Structure-antiproliferative activity studies on L-proline- and homoproline-4-: $\mathrm{N}$-pyrrolidine-3-thiosemicarbazone hybrids and their nickel(II), palladium(II) and copper(II) complexes. Dalton Trans. 2016, 45, 13427-13439. [CrossRef] [PubMed]

26. Kowol, C.R.; Eichinger, R.; Jakupec, M.A.; Galanski, M.; Arion, V.B.; Keppler, B.K. Effect of metal ion complexation and chalcogen donor identity on the antiproliferative activity of 2-acetylpyridine N,N-dimethyl(chalcogen)semicarbazones. J. Inorg. Biochem. 2007, 101, 1946-1957. [CrossRef] [PubMed]

27. Belicchi, F.M.; Bisceglie, F.; Pelosi, G.; Sassi, M.; Tarasconi, P.; Cornia, M.; Capacchi, S.; Albertini, R.; Pinelli, S. Synthesis, characterization and x-ray structures of new antiproliferative and proapoptotic natural aldehyde thiosemicarbazones and their nickel(II) and copper(II) complexes. J. Inorg. Biochem. 2002, 90, 113-126. [CrossRef] 
28. Sîrbu, A.; Palamarciuc, O.; Babak, M.V.; Lim, J.M.; Ohui, K.; Enyedy, E.A.; Shova, S.; Darvasiová, D.; Rapta, P.; Ang, W.H.; et al. Copper(II) thiosemicarbazone complexes induce marked ROS accumulation and promote nrf2-mediated antioxidant response in highly resistant breast cancer cells. Dalton Trans. 2017, 46, 3833-3847. [CrossRef] [PubMed]

29. Onoue, S.; Tsuda, Y. Analytical studies on the prediction of photosensitive/phototoxic potential of pharmaceutical substances. Pharm. Res. 2006, 23, 156-164. [CrossRef] [PubMed]

30. Vargas, F.; Zoltan, T.; Ramirez, A.; Cordero, T.; Chavez, V.; Izzo, C.; Lopez, V.; Cardenas, Y.; Fernandez, A.; Hincapie, L.; et al. Studies of the photooxidant properties of antibacterial fluoroquinolones and their naphthalene derivatives. Pharmazie 2009, 64, 116-122. [CrossRef] [PubMed]

31. De Guidi, G.; Bracchitta, G.; Catalfo, A. Photosensitization reactions of fluoroquinolones and their biological consequences. Photochem. Photobiol. 2011, 87, 1214-1229. [CrossRef] [PubMed]

32. Ioele, G.; De Luca, M.; Garofalo, A.; Ragno, G. Photosensitive drugs: A review on their photoprotection by liposomes and cyclodextrins. Drug Deliv. 2017, 24, 33-44. [CrossRef] [PubMed]

33. Coelho, L.; Almeida, I.F.; Sousa Lobo, J.M.; Sousa e Silva, J.P. Photostabilization strategies of photosensitive drugs. Int. J. Pharm. 2018, 541, 19-25. [CrossRef] [PubMed]

34. Hathaway, B.J.; Billing, D.E. The electronic properties and stereochemistry of mono-nuclear complexes of the copper(II) ion. Coord. Chem. Rev. 1970, 5, 143-207. [CrossRef]

35. Hathaway, B.J.; Tomlinson, A.A.G. Copper(II) ammonia complexes. Coord. Chem. Rev. 1970, 5, 1-43. [CrossRef]

36. MacPhee, J.A.; Panaye, A.; Dubois, J.E. Steric effects-I. A critical examination of the Taft steric parameter- $\mathrm{E}_{\mathrm{s}}$. Definition of a revised, broader and homogeneous scale. Extension to highly congested alkyl groups. Tetrahedron 1978, 34, 3553-3562. [CrossRef]

37. Bicknell, R.T.M.; Davies, D.B.; Lawrence, K.G. Density, refractive index, viscosity and ${ }^{1} \mathrm{H}$ nuclear magnetic resonance measurements of dimethyl sulphoxide at $2{ }^{\circ} \mathrm{C}$ intervals in the range $20-60{ }^{\circ} \mathrm{C}$. Structural implications. J. Chem. Soc. Faraday Trans. 1 1982, 78, 1595-1601. [CrossRef]

38. Árkosi, Z.; Szabó-Plánka, T.; Rockenbauer, A.; Nagy, N.V.; Lázár, L.; Fulöp, F. An electron paramagnetic resonance study of copper(II)- $\beta$-substituted $\beta$-amino acid systems by the two-dimensional simulation method: First evidence of primarily steric effects of substituents on equilibria of metal complexes. Inorg. Chem. 2003, 42, 4842-4848. [CrossRef] [PubMed]

39. Enyedy, É.A.; Zsigõ, É.; Nagy, N.V.; Kowol, C.R.; Roller, A.; Keppler, B.K.; Kiss, T. Complex-formation ability of salicylaldehyde thiosemicarbazone towards $\mathrm{Zn}^{\mathrm{II}}, \mathrm{Cu}^{\mathrm{II}}, \mathrm{Fe}^{\mathrm{II}}, \mathrm{Fe}^{\mathrm{III}}$ and $\mathrm{Ga}^{\mathrm{III}}$ ions. Eur. J. Inorg. Chem. 2012, 2012, 4036-4047. [CrossRef]

40. Diaz, A.; Pogni, R.; Cao, R.; Basosi, R. EPR characterization of a series of mono- and bis-thiosemicarbazone copper(II) complexes. Inorg. Chim. Acta 1998, 275, 552-556. [CrossRef]

41. Kemlo, J.A.; Shepherd, T.M. Quenching of excited singlet states by metal ions. Chem. Phys. Lett. 1977, 47, 158-162. [CrossRef]

42. Horváth, O. Photochemistry of copper(I) complexes. Coord. Chem. Rev. 1994, S135-136, 303-324. [CrossRef]

43. Sies, H. Hydrogen peroxide as a central redox signaling molecule in physiological oxidative stress: Oxidative eustress. Redox Biol. 2017, 11, 613-619. [CrossRef] [PubMed]

44. Sies, $\mathrm{H}$. Role of metabolic $\mathrm{H}_{2} \mathrm{O}_{2}$ generation: Redox signaling and oxidative stress. J. Biol. Chem. 2014, 289, 8735-8741. [CrossRef] [PubMed]

45. Kalinowski, D.S.; Stefani, C.; Toyokuni, S.; Ganz, T.; Anderson, G.J.; Subramaniam, N.V.; Trinder, D.; Olynyk, J.K.; Chua, A.; Jansson, P.J.; et al. Redox cycling metals: Pedaling their roles in metabolism and their use in the development of novel therapeutics. Biochim. Biophys. Acta Mol. Cell Res. 2016, 1863, 727-748. [CrossRef] [PubMed]

46. Jomova, K.; Baros, S.; Valko, M. Redox active metal-induced oxidative stress in biological systems. Trans. Met. Chem. 2012, 37, 127-134. [CrossRef]

47. Pham, A.N.; Xing, G.; Miller, C.J.; Waite, T.D. Fenton-like copper redox chemistry revisited: Hydrogen peroxide and superoxide mediation of copper-catalyzed oxidant production. J. Catal. 2013, 301, 54-64. [CrossRef]

48. Buettner, G.R. Spin trapping: ESR parameters of spin adducts. Free Radic. Biol. Med. 1987, 3, $259-303$. [CrossRef] 
49. Dvoranová, D.; Barbieriková, Z.; Brezová, V. Radical intermediates in photoinduced reactions on $\mathrm{TiO}_{2}$ (An EPR spin trapping study). Molecules 2014, 19, 17279-17304. [CrossRef] [PubMed]

50. Aloisi, G.; Amelia, M.; Barbafina, A.; Latterini, L.; Elisei, F.; dall'Acqua, F.; Vedaldi, D.; Faccio, A.; Viola, G. DNA cleavage induced by photoexcited antimalarial drugs: A photophysical and photobiological study. Photochem. Photobiol. 2007, 83, 664-674. [CrossRef] [PubMed]

51. Wainwright, M. Photodynamic therapy: The development of new photosensitisers. Anti-Cancer Agents Med. Chem. 2008, 8, 280-291. [CrossRef]

52. Jantová, S.; Melušová, M.; Pánik, M.; Brezová, V.; Barbieriková, Z. UVA-induced effects of 2,6-disubstituted 4-anilinoquinazolines on cancer cell lines. J. Photochem. Photobiol. B 2016, 154, 77-88. [CrossRef] [PubMed]

53. Barbieriková, Z.; Dvoranová, D.; Bella, M.; Milata, V.; Czímerová, A.; Brezová, V. Fused-ring derivatives of quinoxalines: Spectroscopic characterization and photoinduced processes investigated by EPR spin trapping technique. Molecules 2014, 19, 12078-12098. [CrossRef] [PubMed]

54. Barbieriková, Z.; Bella, M.; Sekeráková, L.; Lietava, J.; Bobeničová, M.; Dvoranová, D.; Milata, V.; Sádecká, J.; Topol'ská, D.; Heizer, T.; et al. Spectroscopic characterization, photoinduced processes and cytotoxic properties of substituted $N$-ethyl selenadiazoloquinolones. J. Phys. Org. Chem. 2013, 26, 565-574. [CrossRef]

55. Barbieriková, Z.; Bella, M.; Kučerák, J.; Milata, V.; Jantová, S.; Dvoranová, D.; Veselá, M.; Staško, A.; Brezová, V. Photoinduced superoxide radical anion and singlet oxygen generation in the presence of novel selenadiazoloquinolones (An EPR study). Photochem. Photobiol. 2011, 87, 32-44. [CrossRef] [PubMed]

56. Gruttadauria, M.; Buccheri, F.; Buscemi, S.; Cusmano, G.; Noto, R.; Werber, G. Photochemical cyclization of some aldehyde thiosemicarbazones. J. Heterocycl. Chem. 1992, 29, 233-236. [CrossRef]

57. Buscemi, S.; Gruttadauria, M. Photocyclization reaction of some 2-methyl-4-phenyl- substituted aldehyde thiosemicarbazones. Mechanistic aspects. Tetrahedron 2000, 56, 999-1004. [CrossRef]

58. Hayyan, M.; Hashim, M.A.; Alnashef, I.M. Superoxide ion: Generation and chemical implications. Chem. Rev. 2016, 116, 3029-3085. [CrossRef] [PubMed]

59. Zhao, H.; Joseph, J.; Zhang, H.; Karoui, H.; Kalyanaraman, B. Synthesis and biochemical applications of a solid cyclic nitrone spin trap: A relatively superior trap for detecting superoxide anions and glutathiyl radicals. Free Radic. Biol. Med. 2001, 31, 599-606. [CrossRef]

60. Krasnovsky, A.A., Jr. Primary mechanisms of photoactivation of molecular oxygen. History of development and the modern status of research. Biochemistry 2007, 72, 1065-1080. [CrossRef] [PubMed]

61. Brezová, V.; Gabčová, S.; Dvoranová, D.; Staško, A. Reactive oxygen species produced upon photoexcitation of sunscreens containing titanium dioxide (An EPR study). J. Photochem. Photobiol. B 2005, 79, 121-134. [CrossRef] [PubMed]

62. Stoll, S.; Schweiger, A. EasySpin, a comprehensive software package for spectral simulation and analysis in EPR. J. Magn. Reson. 2006, 178, 42-55. [CrossRef] [PubMed]

63. Duling, D.R. Simulation of multiple isotropic spin-trap EPR spectra. J. Magn. Reson. B 1994, 104, $105-110$. [CrossRef] [PubMed]

Sample Availability: Not available.

(C) 2018 by the authors. Licensee MDPI, Basel, Switzerland. This article is an open access article distributed under the terms and conditions of the Creative Commons Attribution (CC BY) license (http://creativecommons.org/licenses/by/4.0/). 